\title{
SEXUAL BIOLOGY, CHROMOSOMES, DEVELOPMENT, LIFE HISTORIES AND PARASITES OF BOREUS, ESPECIALLY OF B. NOTOPERATES. A SOUTHERN CALIFORNIA BOREUS. II. (MECOPTERA: BOREIDAE)*
}

\author{
By Kenneth W. Cooper \\ University of California, Riverside \\ California 92502
}

\section{INTRODUCTION}

This, the second of three accounts devoted primarily to Boreus notoperates Cooper, deals with aspects of its life history. The subjects include, among others, sex ratio, mating, developmental stages, a brief comparative account of its cytology, its host mosses and peculiar adaptation to a life in their thin sods on diorite boulders in a region annually subject to long periods of drought and considerable heat. All of this is placed in a framework of what is now known for the other species of Boreus on these topics.

Though some fifty or so articles are referred to or discussed that are devoted to, or comment upon, Boreus, there are an additional sixty to seventy more papers and accounts which, though all have been consulted, either do not bear directly on the topics treated, or seem wholly derivative. My choice of references is based upon their substantial treatment of a subject, their content of new observations or ideas, or the need to correct a standing error. To these sources, I have added my own unpublished observations on $B$. brumalis Fitch and $B$. nivoriundus Fitch where relevant. The overall aim, then, is to draw together, to compare, and, where possible, to generalize what is known of the species of Boreus on the topics presented and on which I have information derived from $B$. notoperates.

Among the matters given emphasis are: the likelihood that species of Boreus have a sex ratio approaching equality (a debated topic); the fact that $B$. notoperates is the only species (of eight for which information is known) that deviates in its mating; the curious reciprocal intromission at mating by male and female alike, and the anatomical relations of their parts; the conservative nature of the chromosomal cytology of Boreus and other scorpion flies as compared with Panorpa; the prevalence of a larval epistomal suture, which

*Manuscript received by the editor February 10, 1974. 
bears upon the tenability of the order Neomecoptera that specially sets Boreus apart from other scorpion flies; the likelihood that Boreus, like other Mecoptera, has four larval instars; the occurrence of both pupal and adult pharate stages in development; that whatever limits the distribution of a species of Boreus, it is not its host mosses; and finally, that Boreus species, despite their peculiar life cycle, may have an obligate hymenopterous parasite, a matter which puzzled Withycombe. The third and final article will deal with the range of habitats species of Boreus have entered, the mosses with which Boreus species are associated, interpretation of Boreus as a winter insect, and a reconsideration of its distribution in relation to drift and glaciation.

\section{Occurrence and Span of Adult Activity}

Boreus notoperates has so far been collected at two localities only, both being NW faces of steep canyons, at $12 \mathrm{rgm}$ altitude (Coldwater Canyon) and at $1645 \mathrm{~m}$ (Black Canyon), on Mt. San Jacinto, Riverside Co., California. The first is a yellow pine - chaparral ecotone (Pinus ponderosa Dougl. - Adenostoma fasciculatum Hook. and Arn.) that is Upper Sonoran, or Upper Austral in Merriam's ( 1898 ) original sense, the mean temperature for the six hottest weeks (July through mid-August) being $\sim 24^{\circ} \mathrm{C}$. The second is a mixed woods of yellow pine, incense cedar, white fir and canyon oak (Pinus ponderosa, Libocedrus decurrens Torr., Abies concolor Gord. \& Glend., and Quercus chrysolepis Liebm.), fringed and penetrated by chaparral elements; it is Transitional, the corresponding high mean temperature being about $2 \mathrm{I}^{\circ} \mathrm{C}$. Over the period $\mathrm{I} 955-7 \mathrm{I}$ the mean annual precipitation (close by at the Idyllwild Fire Station, alt. $1645 \mathrm{~m}$ ) was $59.6 \mathrm{~cm}$ (23 in.), with $74 \%$ falling in the months of November through March during which adult $B$. notoperates have been collected. The adults have so far been found only on mosses growing on boulders and large jointed blocks of diorite, or on snow about them, in both fairly open (chiefly Coldwater Canyon) and shaded (chiefly Black Canyon) situations. Even during the period of winter precipitation the mosses are only periodically dampened and luxuriant, for precipitation is widely scattered, and melts rapidly when snow. The activity of Boreus at all its stages coincides with those periods, frequently brief and generally spaced out, when the mosses and their roots are damp. At other times the relative humidity is low, the mosses are dry to the touch, even friable, and their sods 
crumbly or powdery. In periods of desiccation Boreus are found, if at all, with difficulty, unless a special method is used.

The earliest that adult Boreus notoperates have been taken was mid-November, several days following the second snowfall of an inch or more, although it is likely that a snow or a soaking rain in October would bring them forth to judge from laboratory emergences of pupae collected in mid-August. Thereafter adults have been found during the damp periods in all months until mid-March, when they become rare. Air and surface temperatures have been mild when adults have been collected, ranging from a low of $6.1^{\circ} \mathrm{C}$ to $18.3^{\circ} \mathrm{C}$, though in the November through March interval below freezing temperatures are not uncommon, mean low temperatures for these months ranging from $-4.2^{\circ} \mathrm{C}$ to $3.2^{\circ} \mathrm{C}$, with absolute lows to $-\mathrm{I} 2.2^{\circ} \mathrm{C}$.

\section{Sex Ratio and Spanandry}

The sex ratio among adult $B$. notoperates from field collections, though slightly skewed toward an excess of males early in the season, of females late in the season, does not depart from equality; thus: $1310^{x} 0^{x}$, 150 우 (of which 32 of each sex were collected as mated pairs); chi-squared gives $0.3>\mathrm{P}>0.2$. Nor is there a departure from equality among immature stages collected in mid-August and early September. For 47 such larvae and pupae we have:

29 late instar larvae and pharate pupae of which:

I9 sexed by dissection of gonads, giving: $120^{\pi} 0^{\pi}, 7$ 우 우 ;

Io pupated, giving: $60^{x} \sigma^{x}, 4$ 우우;

I 8 pupae when found, of which: $70^{7} 0^{\pi}$, II $9+9$; which gives a sex ratio of $250^{\pi} 0^{\pi}: 22$ 우, for which $0.7>\mathrm{P}>0.5$.

Now Strübing (1950) has shown from extensive field and laboratory observations that males of Boreus hyemalis (L.) do not tend to emerge earlier than females in the autumn. They do, however, tend to die off somewhat earlier than females, and this has been claimed or inferred by others both from field and laboratory observations (e.g., Withycombe 1922, Syms 1934, Cotton 1971; and for $B$. westwoodi Hagen, Brauer 1855 ; for an undescribed species?, Kolenati 1847$)^{1}$. My own observations on $B$. notoperates are in

\footnotetext{
${ }^{1}$ Strübing (1950) gives strong reason to believe that Brauer's species is almost certainly $B$. westwoodi, and not $B$. hyemalis as he and others have thought. Furthermore, Pliginsky (1930) states that Kolenati's specimens, from the glacier of Aar (Kazbek, Kaukas), no longer can be found, and are very likely an undescribed species. From Kolenati's comments, they fall among the species with a reduced antennal joint number $(\sim 20)$.
} 
agreement. But it has also been claimed, as early as Hardy's ( 1848 ) and MacLachlan's ( 1868 ) notes, that the sex ratio of Boreus is spanandrous, but only loosely in Marchal's (I9II) sense, namely that males regularly make up a minority of the population. Not surprisingly, small collections of Boreus may show a predominance of one sex. In general, however, collections of two dozen or more specimens at a locality, but not made at the season's close when females do tend to predominate, give sex ratios which approximate equality, as do those for $B$. notoperates. There are, however, exceptions. But for none of the following records is there a significant departure (namely, $\mathrm{P}<0.05$ ) from equality of the sexes:

\begin{tabular}{|c|c|c|c|}
\hline I. B. brumalis Fitch & $270^{x} 0^{x}$ & $26 ㅇ ㅜ ㅇ$ & $\begin{array}{l}\text { (Hanover, N. H., } \\
\text { Cooper, unpubl.) }\end{array}$ \\
\hline B. coloradensis Byers & $2 \mathrm{I}$ & 20 & (Byers I955) \\
\hline 3. B. unicolor Hine & 64 & 57 & (Chapman I954) \\
\hline \multirow[t]{5}{*}{ 4. B.hyemalis (L.) } & 39 & $4 \mathrm{I}$ & $\begin{array}{l}\text { (sifting, Druet \& Le- } \\
\text { gros, ex Lestage I94I) }\end{array}$ \\
\hline & 33 & 45 & $\begin{array}{l}\text { (table I, to Dec. 20, } \\
\text { Strübing I950) }\end{array}$ \\
\hline & 103 & IIO & $\begin{array}{l}\text { (table } 4 \text {, not text p. } 84 \text {, } \\
\text { Strübing } 1950 \text { ) }\end{array}$ \\
\hline & 19 & II & $\begin{array}{l}\text { (Schürmann, ex Strüb- } \\
\text { ing I950) }\end{array}$ \\
\hline & 38 & 45 & $\begin{array}{l}\text { (pitfall traps, Cotton } \\
\text { I97I) }\end{array}$ \\
\hline \multirow[t]{3}{*}{ 5. B. westwoodi Hagen } & 60 & 64 & (Martynova I954) \\
\hline & 24 & 25 & (Martynova I954) \\
\hline & 12 & I 4 & (Martynova I954) \\
\hline B. bey-bienko & 56 & . & (Tarbinsky i96o) \\
\hline
\end{tabular}

As exceptions, with probabilities $<0.02$ to $<0.001$ as random departures from equality of the sexes, we have:

7. B. nivoriundus Fitch $420^{\pi} 0^{\pi} 23$ 우우 (Hanover, N. H.

8. B.hyemalis (L.) $398 \quad 123 \quad \begin{aligned} & \text { Cooper, unpub } \\ & \text { (Steiner 1937) }\end{aligned}$

9. B. westwoodi Hagen $97 \quad 67 \quad$ (3 collections, data homogeneous, Fjellberg \& Greve 1968)

Judging by records $\mathrm{I}-6$, and from the proportions among immature stages which have been sexed, the records 7-9, all of which show a significant preponderance of males, may reflect a tendency for 
males to wander widely at times in search of females, or true peculiarities of the particular populations, or perhaps of the mode or circumstances of collecting. Strübing's (1950) laboratory rearings of $B$. hyemalis gave $400^{\top} O^{\top}, 36 q \%$, and Fraser's (1943) account implies that his collection (in September) of pupae of $B$. hyemalis consisted of $290^{x} \sigma^{x}$, 21 우 (for which $0.3>\mathrm{P}>0.2$ ). My own collection of larvae, pharate pupae, and pupae of $B$. nivoriundus in August, at the same site in Hanover, N. H., at which the adults scored in 7 above were later collected (December to mid-April), gave $300^{\pi} O^{\lambda}, 33$ 웅. Pupae of B. brumalis collected (from October to mid-November) at Princeton, N. J., likewise do not depart from an equality of sexes: $40 \sigma^{\pi} \sigma^{x}, 46 q 9$. As Strübing (1950) concluded, the sex ratio in Boreus appears to be close to unity for both immature stages and adults, as is the case for $B$. notoperates. The answer to Lestage's ( I94I) question "is there spanandry in Boreus?" must be: "not so far as known, and perhaps not at all," as Lestage suspected. Indeed, the only significant departures so far recorded are in fact spangynous, not spanandrous.

\section{MAting}

Mated pairs of $B$. notoperates are found chiefly on patches of damp moss, free of snow, from early in November to near the middle of March. Although Fraser (1943) claimed B. hyemalis to be crepuscular, there seems to be no special time of day that is favored for mating by $B$. notoperates if the temperature is mild; nor is light a requirement, for $B$. notoperates mates readily in the dark (in an incubator, at $9^{\circ} \mathrm{C}$ ). In but one case (of 33) has a mated pair been found on the snow, and that mated pair had most likely fallen a foot or so out onto the snow from a steep, moss-covered rock-face. Certainly the suggestion that Boreus occurs on snow because it is easier to find mates there is implausible; the rule seems to be that mating generally occurs on or in moss, where they congregate when it is available to the insects.

Nine complete matings of $B$. notoperates have been observed, namely from the first attempts of the male to gain a partner to the completion of intromission, as well as a good many partial sequences from all stages in the routine. $B$. notoperates is without a courtship, just as in the three species for which the course of events of mating have been described, namely $B$. westwoodi (Brauer 1855, I863, 
Sauer I966, perhaps Svensson I966²), B. hyemalis (Withycombe 1926, Syms 1934, Steiner 1937), and B. brumalis (Cooper 1940, Crampton 1940). From its very onset the affair is between a "coy" female acting as though bent on escape, and an aggressive, though not necessarily persistent, male. An ardent male, when within some millimeters range, springs at the female, ensnaring her with his tonglike wings while seizing whatever he can of her extremities with one or both of his genital claspers (or gonostyles). If he fails to gain a hold, as he occasionally does, the female leaps away and is not directly pursued. Thereafter the male either takes a waiting stance on a sprig of moss, or courses about the moss, in both cases twitching his wings and opening and flexing his gonostyles from time to time. ${ }^{3}$ When chance again presents another or the same female, the male attempts once again to gain a firm hold of the female.

When a mating spring has been successful, the male may have seized a female by a posterior femur ( 5 cases), a mid-tibia ( 2 cases), a protarsus ( I case), or the antennae ( $\mathrm{I}$ case). In some other instances, in which only a part of the mating routine was followed, males had gained holds simultaneously of both a mid- and fore-tarsus, or a foretarsus and antenna, or a mid- and hind-tibia, and so on. The initial hold thus seems fortuitous and not limited to a particular appendage or to but one appendage at a time. Depending upon the particular grip of the gonostyles, and the appendage(s) seized, a male may either face opposite to the captured female ( 7 cases), and may even be chiefly behind her, or face in the same direction as his partner. When a female's femur or tibia has been grasped, a male, without loosening or losing his hold, can generally draw his own body about to a position at right angles to that of the female by forcibly rotating her appendage, but he cannot wholly reverse the direction in which he faced without obtaining an entirely new hold, as he must when initially facing $\mathrm{I} 8 \mathrm{O}^{\circ}$ away from his partner.

Once seized, the female's response is immediate and energetic, as though designed to free her from the clinging, intermittently passive, male. She drags the male on his back, his side, or even vertically on his hypopygium, over and through obstacles presented by the moss and debris. Occasionally the male acts to resist, splaying his legs outward as though a drag-anchor, or clutching at the moss, offering

\footnotetext{
${ }^{2}$ ? Also Svensson (1966), whose account must refer to B. westwoodi, to $B$. hyemalis, or to both.

"Terminology referring to the external male "genitalia" follows Michener (1944).
} 
such resistance to the female as he can. From time to time the female rests, and may even pause to feed at rosettes of young moss leaves. At such times the male becomes enlivened, rights himself, turns the length of his body at right angles to the female's while still holding his original grip with his gonostyles, and swiftly (and repeatedly) arches backward over the female in an endeavor to gain firm grasp of her body with his wings. If he fails and rests, the rebellion of the female returns unabated and continues, as just described, until the male succeeds in subduing her, or she finally rids herself of him. ${ }^{4}$

Should the male succeed in gaining a firm hold with his stiff, spined and hooked wings, he deftly changes grip with his gonostyles so that he now faces in the same direction as the female. Once a position has been attained from which he can rear backward and to the side of the female, and grasp her between her head and mesonotum with his wings, holding her body parallel to his own, he again quickly moves his gonostylar grip forward. Once a sufficiently forward grip with the gonostyles has been gained, the head of the female now being behind the male's forebody, he rears strongly backward a number of times and rakes and manipulates the female's rostrum and antennae with his spined wings as he falls forward again. Should he gain hold of the female's pronotum with his wings, he may move his gonostylar grip from the female's legs to clutch one or both antennae, and then briefly but smartly, drag her about by the antennae. Mauling of the antennae is quickly followed by a wholly passive state on the part of the female who thereafter stands as though mesmerized. Surprisingly, on the initial assault in one case, the male seized the female's antennae with his gonostyles; that female thereupon became submissive without a struggle.

When the standing female has become passive, the male (still anterior to the female and gripping an appendage with his gonostyles) again bows backward repeatedly until his groping wings gain a secure hold behind her head, to each side of the pro- or mesonotum, with the female's head pressed sharply and to the side by his flank. The gonostylar grip is then moved as far posteriorly as the male can manage, and the wing grip released. Once the male has the female again firmly gripped with his wings, and the gonostyles reach sufficiently far backwards, he tries to seize the ovipositor with his gonostyles; ordinarily several attempts are required, and after each failure

\footnotetext{
${ }^{4}$ Maréchal (1939) misremembers Lestage's (1920) account when he states "c'est la $\&$ qui saute sur le $\hat{o}$, celui-ci cherchant à fuir et a s'en débarasser!", and goes on to tell still more of female sexual aggressiveness.
} 


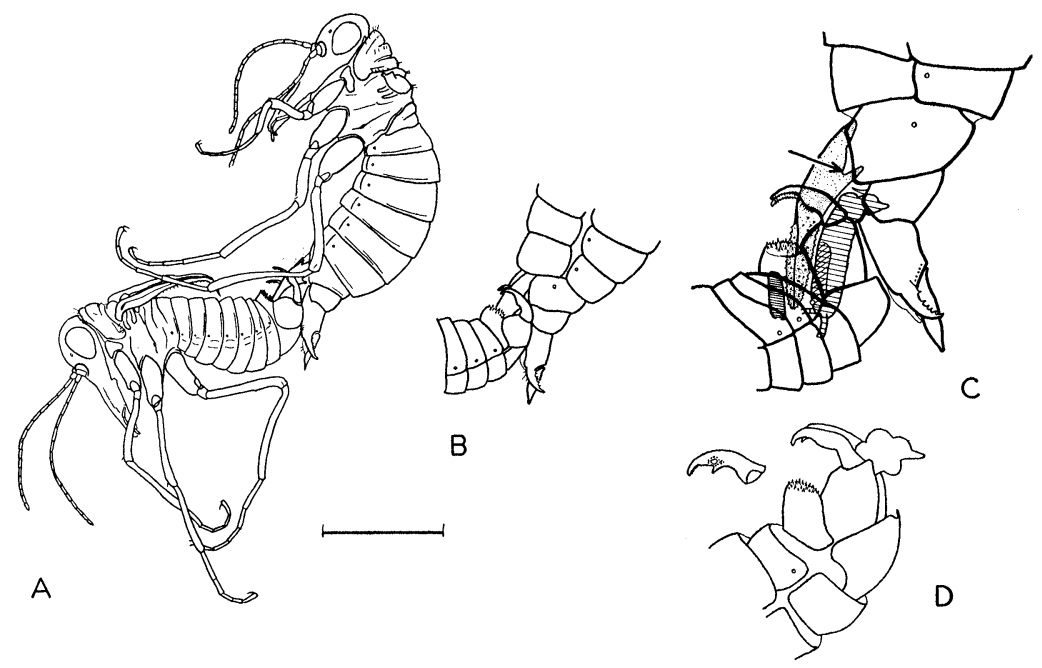

Fig. 1. Mating of Boreus notoperates. A, mated pair preserved in female perpendicular position; the medial tooth of the gonostylus has disengaged (at death) from the lateral basal notch of the gonapophysis. B, full union of male and female; medial tooth of gonostylus seated into the lateral basal notch of the gonapophysis; $\mathrm{C}$, semi diagrammatic representation of mated specimens cleared in clove oil; as in A, the gonapophysis is partially withdrawn from the endandrium, and the lateral basal notch of the gonapophysis (at arrow) is clearly visible; dorsal proctigeral plate (closely, transversely lined) lies within epandrial notch; gonapophyses stippled; aedeagus (widely, transversely lined) partially inserted in common oviduct - note flap at anterior margin of female gonopore and paired ejaculatory ducts entering base of aedeagus; the sclerotized lamina that forms floor of endandrium is cross-hatched (see text). D, male terminalia with everted aedeagus, apical nipple of which bears the gonopore; upper left - inner face of right gonostyle to show median tooth and stylocavernula. All from camera lucida sketches; scale: for $\mathrm{A}$ and $\mathrm{B}$ equals $1 \mathrm{~mm}$, for $\mathrm{C}$ and $\mathrm{D}$ equals $0.5 \mathrm{~mm}$. 
the gonostyles are returned to a grip on the posterior legs, near the coxae, and the male rests. When at last the ovipositor has been grasped, the gonapophyses are pried down and slightly apart, the female holding them, as though plastic, in whatever position they were released by the gonostyles. The gonapophysis of each side is then engaged between the inner tooth and the tip of the corresponding gonostyle which, on adduction, directs and thrusts the tip of the gonapophysis into a pocket ventral to the epandrium (see below). Ratchetlike, the two gonapophyses together are worked down and in by the gonostyles. Finally each gonostyle becomes securely seated on the corresponding gonapophysis, for its inner tooth (figs. ID; $2 \mathrm{~A}, \mathrm{~B})^{5}$ engages the lateral notch of the gonapophysis near its base (fig. IB, compare with $\mathrm{IA}$ and $\mathrm{C}$, arrow).

The female is then released from the clasp of the male's wings. Thereupon she rocks backward $90^{\circ}$ or more, with rostrum and antennae folded between the forelegs, femora drawn up to the sides, tibiae adducted, tarsi drooping - the "death-feigning" posture that concludes the leap of a startled Boreus. Surprisingly, the female thereafter remains vertically in that posture, though her legs relax, and the male folds his wings to their usual rest position over the back, fig. I A). In side view it can be seen that the tip of the aedeagus has been fully inserted into the common oviduct (fig. IC). Despite the unbalanced appearance of a male and female united thus at a right angle, without any noticeable difficulty the male may run, climb, feed, and hop, landing without loss of balance. If startled, the male may leap several centimeters or more, landing in (or assuming) the death-feigning posture, motionless and resting on his flank; the female too death-feigns as before; after a few moments, the male returns to his feet.

In all, ten cases have been timed from the first assault of the male to intromission; these took from 6 minutes to 18 , with a mean of I 3 minutes (all at $17^{\circ}-20^{\circ} \mathrm{C}$ ). The total duration of intromission has not been timed, but I have observed cases in which it was less than an hour, others of more than several hours. Both sexes mate repeatedly, with the same or different partners.

\footnotetext{
${ }^{5}$ Esben-Petersen (1921) was unable to see this median tooth in specimens before him of $B$. brumalis and B. nivoriundus; Lestage (1940) took the supposed absence of a median gonostylar tooth as presenting a cardinal character for Euboreus, a genus he erected for all American species. For discussion of Euboreus, see Cooper (1972).
} 


\section{Discussion of Mating}

The events just described are different in a number of significant features from those in the matings of $B$. hyemalis, $B$. westwoodi and $B$. brumalis, which are alike. Once a female of those species has been seized by a male, it ordinarily becomes passive (but not always, see Syms 1934, Aubrook 1939, Sauer 1966, Crampton 1940). The rested male then grips the female across the midbody with his wings (as does $B$. notoperates), and with them and his gonostyles works her body over his dorsum so that it is axially symmetrical and parallel to his own. The gonapophyses are then pried down and inserted into the subepandrial pocket, the wing-hold is released and the female rocks back until perpendicular to the male. Intromission very likely occurs at this point, as it does in $B$. notoperates. The relative station of the two sexes just prior to intromission, or the "pose" (Lamb $\mathrm{I} 922$ ), in all four species is truly a "female vertical pose" with (presumably) an inverse correlation of the genital conduits of the two sexes. ${ }^{6}$

Now Lamb (I922) used "vertical" as a contrasting term to "linear" (or tail to tail) to denote arrangements of partners in which one partner is above the other. In the overwhelming majority of such cases, the body of the upper insect lies more or less parallel to that of its partner. Consequently I shall call the pose common to the four Boreus a "female perpendicular pose" to distinguish it. The final copulatory attitude of $B$. notoperates does not depart from the pose; accordingly it is a "female perpendicular position" (fig. IA). In contrast, $B$. hyemalis, $B$. westwoodi, $B$. brumalis, $B$. californicus (= var. fuscus Carpenter?) (Cockle I908, I914), B. nivoriundus Fitch (Carpenter 1936; Cooper, unpubl.), B. unicolor Hine (Byers I954) and B. vlasovi Martynova (Vlasov I950), namely in all other species for which the copulatory position has been recorded, the final attitude differs from the pose, being a female vertical position. ${ }^{7}$

\footnotetext{
${ }^{6}$ On intromission, the apparent dorsal wall of the aedeagus of Boreus lies in contact with the ventral wall of the common oviduct, hence in "inverse correlation", which is unusual (fig. 1C). In most insects correlation is "direct", or symmetrical, for contact is dorsal-dorsal and ventral-ventral; in many insects having a vertical position, direct correlation is brought about by rotation of the male genital tract (see Lamb 1922).

${ }^{7}$ For original drawings, or photographs (reference in boldface), of copulating pairs in their final female vertical position, see: for B. hyemalis, fig. 3, pl. 8, Withycombe (1922), fig. 1, Steiner (1937), fig. 7, Strübing (1958) ; for B. westwoodi, fig. 5, pl. 3, Brauer (1855), fig. 2, Sauer (1966); for B. brumalis, fig. 9, Cooper (1940), fig. 1, Crampton (1940).
} 
On the basis of its morphology, $B$. notoperates (along with the similar $B$. brevicaudus Byers) has been adjudged the least primitive of all known species of Boreus (Cooper 1972). Interestingly, its mating stands apart from that described for the other three studied species: at its onset (the enduring resistance by the female), at its midpoint (submission by the female only after antennal "abuse"), and at its very end (a female perpendicular position derived without change from a similar pose). In that last attribute, it differs from all seven other species of Boreus for which the position has been recorded and, notably, that position is alike in all seven. The long period of female coyness and the need for manipulation of the female's antennae go hand in hand, but I cannot decide whether these are primitive aspects or not. But the female perpendicular position is almost certainly a specialization, the marked change from pose to position that occurs in other species of Boreus most likely being primitive. I suspect that the presumed loss of change is related to the unusually shortened ovipositor of $B$. notoperates and the relative depth to which the gonapophyses are inserted into the male; if that is so, $B$. brevicaudus may be expected to have a female perpendicular position, and possibly also the remote $B$. chadzhi-gireji Plikinsky as well.

Because most Boreus follow closely similar mating patterns, as do $B$. brumalis and $B$. nivoriundus, with poses and final positions that are alike, the question quite naturally arises as to whether crossmatings occur or are even attempted. My own trials on this score were with smallish $B$. nivoriundus males and $B$. brumalis females, two species quite frequently found within common areas in New Hampshire. They showed no mutual interest whatsoever. This was not to be attributed to lack of potential competence or sexual aggressiveness on the part of the males for, when female $B$. nivoriundus were added, the males soon paired, or attempted to do so, with the females of their own species. Perhaps the scent or secretion claimed for female Boreus (Hardy I848, Withycomb I922, Maréchal 1939) has a role as a species specific mating pheromone.

\section{The Anatomical Correlations in Mating}

The female vertical position is widespread among insects, yet not common. It has been recorded for Orthoptera (where it, or its equivalent, the "false male vertical position" of Richards, is the usual mode), Plecoptera, Mallophaga, Anoplura, Mecoptera, Siphonaptera, 
Diptera (as Empis), and Coleoptera (Lomechusa) (Meisenheimer I92 I, Richards 1927), as well as for aradids (Heteroptera) (Usinger and Matsuda 1959). For the majority there is little information on the correlation involved, but it is probably generally inverse, with the anus of the female unobstructed, as in Boreus. The similarities cease here, however, for so far as I am aware the species of Boreus are unique in their adaptation to, and practice of, a reciprocal intromission - namely a concurrent passage of the female's gonapophyses into a specialized genital pocket within the male, and of the aedeagus into the common oviduct (fig. IC). This curious arrangement was first commented upon by Cockle (1908, I914), and later by Steiner (1937) and Cooper (1940), but it has not properly been described.

Projecting cephalad from the medio-dorsal aspect of the gonocoxites of the male, there are two sclerotized laterally flattened straps, the dorsal apophyses of the gonocoxite, that expand medially and unite to form a thin, broad, pigmented roofing plate that lies below the anus (figs. 2A, B; fig. 4, Cooper 1972). The more dorsal anus is itself enclosed by sclerotized dorsal and ventral proctigeral plates (segments $X+X I$ ?) (fig. $2 A$; fig. 3, Cooper 1972). ${ }^{8}$ Ventral to the gonocoxital roofing plate, or dorsal portion of the gonobase, there is a broad, sclerotized band overlying the dorsum of the aedeagus (figs. IC, 2A, B; also fig. 4 Cooper 1972). A wide, enclosed, shallow but elongated pocket is thus formed between the dorsal gonobase, the muscles of the gonocoxites, and the sclerotized band over the aedeagus. In the unmated male at rest, this pocket (which I call the endandrium) curves downward under the epandrium (fig. $2 \mathrm{~B}$ ).

Just prior to insertion of the aedeagus, the gonapophyses (sternitesVIII, or "ventral valves of the ovipositor") are thrust by the male into the endandrium. The main fields of caudally-directed spines on the bosses to each side of the epandrial notch (fig. 2A) catch on the outwardly directed denticles of the blades of the gonapophyses, preventing slippage outwards as the gonapophyses are initially forced, ratchet-like, more and more deeply into the endandrium. Once fully inserted within the endandrium, the gonapophyses are locked in place there by the gonostyles of the male. Not only is the blade of each gonapophysis grasped tightly between the apex and inner tooth of a gonostyle, but that inner tooth of each gonostyle is in turn engaged by being seated into the lateral basal notch of its corresponding gonapophysis (fig. I B $c f . \mathrm{A}, \mathrm{C}$, arrow). That union so forcibly locks the

\footnotetext{
${ }^{8}$ The proctigeral plates ( $=$ segment-XI) in the female of Boreus notoperates are similar to those of B. brevicaudus, described by Byers (1961).
} 

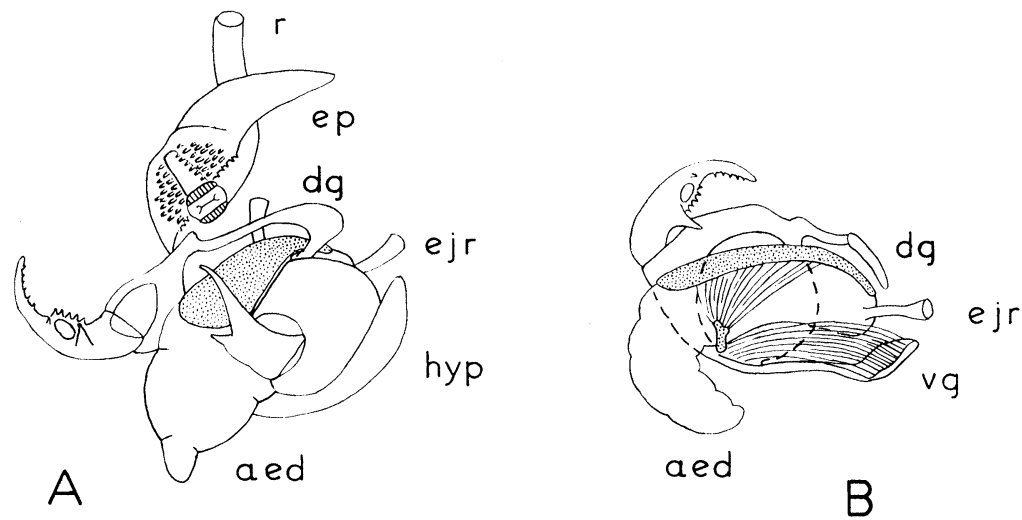

Fig. 2. Genital anatomy of male Boreus notoperates. A, terminalia viewed obliquely from the right side. The epandrium (ep), or tergite-IX, has been separated from its articulations on the right, and reflected about $60^{\circ}$ to the left. The anus, enclosed by proctigeral plates (cross-lined) lies immediately below the epandrial notch, the spined epandrial bosses to each side. Gonostyles abducted on right, displaying in profile the short, sharp medial tooth which engages the lateral basal notch of the gonapophysis. The dorsal gonobase (dg) extends anteriorly from the gonocoxites, flaring out as the roof of the anterior end of the endandrium. Median plaque (stippled) immediately over the aedeagus forms the floor of the endandrium; aed - partially everted aedeagus, ejr - right ejaculatory duct, hyp - hypandrium, $\mathrm{r}$ - rectum.

B, partially exserted aedeagus (aed), right lateral view. Epandrium, proctiger, right gonocoxite and hypandrium have been removed. Above, dg, the left dorsal half of the gonobase; below, vg, the left ventral half of the gonobase. Sclerotized plaque (stippled) overlying the aedeagus joined by a fan of muscles to U-shaped sclerite (stippled) partially encircling the aedeagus ventrally. The genital chamber is the space enclosed between the dorsal and ventral gonobases, the endandrium lies between the dorsal gonobase and the sclerotized plaque, and the aedeagal chamber lies between the sclerotized plaque and the ventral retractor muscle attached to the ventral gonobase; ejr - right ejaculatory duct. Both figures from camera lucida drawings; scale equals $0.5 \mathrm{~mm}$. 
mated pair together that, unless the male's grip is loosened, the female cannot free herself. In all but $B$. notoperates, the female is then rocked forward into the final female vertical position. Although the spines of the epandrial bosses may once again act against denticles of the gonapophyses' blades, preventing slippage, and the male's wings give an added grip, the change in position seems a supererogation so far as security of the male's mating grip is concerned.

The aedeagus, at rest, lies within a chamber that may be distinguished from the endandrium. The roof of the aedeagal chamber is the band-like sclerotization over the aedeagus which forms the floor of the endandrium; the side walls are in part defined by the internal faces and musculature of the gonocoxites, and the floor of the chamber by the cephalad-directed apodemal band from the antero-medial, ventral angle of each gonocoxite that joins its homolog as a broadening, very thin strap, the ventral gonobase (fig. $2 \mathrm{~B}$ ) which, in some specimens, encloses a minute medial sclerotized plaque. The space enclosed between the dorsal and ventral gonobases, then, forms the genital chamber proper, and the endandrium and aedeagal chambers are thus dorsal and ventral subdivisions of it.

The aedeagus itself is a heavily muscled tube containing the unpaired ejaculatory duct. At rest it is hook-shaped, with its hooked tip wholly withdrawn into the aedeagal chamber, resting upon the ventral adductor muscle (fig. $2 \mathrm{~B}$ ). The paired ejaculatory ducts separately enter the caudal end of the aedeagus (figs. IC, 2A, B), uniting within it. Above the aedeagus is the sclerotized band that serves as floor to the endandrium. Below, near the point at which the aedeagus bends back on itself in its distal third, there is a slender, sclerotized hoop which partially encircles the aedeagus on the ventral side, from which a fan of muscles extends dorsally and caudally to insert on the dorsal sclerotized band. In $B$. borealis Banks, ${ }^{9}$ and $B$. coloradensis Byers, there is both a dorsal and ventral sclerotized longitudinal band between which the aedeagus lies.

The contraction of the muscles running from the ventral hoop to the floor of the endandrium both enables the aedeagus to be held and packed in retraction within the genital chamber and, when the aedeagus is everted, to reduce the space of the aedeagal chamber and thus force the aedeagus caudally outward. No doubt, to judge from the anatomical relations of the endandrium, the initial downward

\footnotetext{
${ }^{9}$ The Whitney's field-notes suggest that Banks, when describing B. borealis, had but two of a total of four specimens that were captured; see records 129 and 157, pp. 136-137, in McAtee (1923).
} 
thrust and pressure of the gonapophyses in the endandrium are additional (perhaps necessary) factors in the eversion and erection of the aedeagus. Contraction of the annular musculature of the aedeagus itself additionally extends the organ and causes the tip to inflate into a bulb, bilobed dorsally, which abruptly terminates in a conical, or nipple-shaped tip upon which the ejaculatory duct opens (fig. ID). The fully extended aedeagus runs between, and is guided by, the smooth inner faces of the gonapophyses and the ventral surface of the ovipositor to enter the common oviduct, from the anterior ventral margin of the orifice of which extends a chitinous guiding flap that, at other times, closes the aperture (fig. $\mathrm{IC}$ ). Once entered into the oviduct, the apical bulb of the aedeagus is inflated within the vestibule of the common oviduct which opens at the junction of segments IX and $X$. In that position the ventral bulge of the bulb evidently blocks off the common duct of the tubular accessory glands of the oviduct, and the conical tip of the aedeagus enters the short spermathecal duct, within which there is a minute sclerotization (fig. 9, Cooper 1972). Insemination therefore takes place directly into the duct of the spermatheca.

The account just given will very likely be found to agree in its main features with the complex "reciprocal intromission" of other Boreus, even though Martynova's (1954) figures I-6 hint that the endandrium may differ in depth and conformation among different species. However it is at variance with Steiner's (1937) description (or inference?) for B. hyemalis in which the tips of the gonapophyses are said by him to be received directly and separately into the pockets of the epandrium. That is not the case in still other mated Boreus ( $B$. brumalis, $B$. nivoriundus) that I have studied, and in which endandrial insertion occurs. Nor is it likely that the condition observed by Byers (1954) in a preserved, mated pair of Boreus unicolor Hine is a normal state of affairs; namely that the tips of the gonapophyses are bent across one another, and are held thus by the gonostyles of the male at right angles across his epandrium. Nor does B. notoperates conform to Potter's (1938b) description for $B$. hyemalis of a coiled or folded ductus ejaculatorius (see her fig. 30) which, at rest, is thrown into three flexures within the genital chamber, and which is evaginated during coition. As Steiner said, the intromittant organ is strongly muscular, and as I have shown it is in effect erected without evagination comparable, say, to that of a true internal sac. The element which Potter figures in front of the first distal flexure, appearing continuous in her figure with the "ejacula- 
tory duct," is very likely the large retractor muscle in my figure $2 \mathrm{~B}$ which occupies that position in B. notoperates. Brief comment on the aedeagus of Boreus will be found in Fitch (1847), Kolenati (1847), Cockle (1908, 1914), and Byers (1954), as well as in Withycombe (1926) and Crampton (1918, 1920, 1923, 193I) who have figured it in an everted state. To judge from these figures and my own, species of Boreus may differ in the apical morphology of the aedeagus.

\section{Cytology}

Boreus notoperates has a diploid number of 20 in the female and 19 in the XO male. At spermatogenesis, the autosomes are conjoined by chiasmata (nearly always but one per bivalent) that are interstitial or proterminal at diakinesis, but for the most part terminalized by metaphase-I. There is only a moderate premetaphase stretch.

The acrokinetic $X$ is the largest chromosome of the set (from 7-9 $\mu$ long), being respectively two to five times the lengths of the largest and smallest autosomes. The $\mathrm{X}$ possesses a nucleolus organizer proximally in the long arm. Spermatogenesis is orthodox, the $X$ segregating precociously and reductionally at anaphase-I. At anaphase-II, as at anaphase in both spermato-and oogonial mitoses, the separating chromatids of $\mathrm{X}$ stretch and span the entire length of the elongating spindle before their distal tips disjoin.

The chromosome number of $B$. notoperates is the lowest so far known for Boreus $\left(B\right.$. brumalis, $\mathrm{n}^{\star}=\mathrm{II}+\mathrm{X}_{1} \mathrm{X}_{2}, \mathrm{Y} ;$ B. hyemalis, $\mathrm{n}^{7} \sim \mathrm{I}_{4}+\mathrm{X}, \mathrm{O} ; B$. nivoriundus $\mathrm{n}^{\top}=15+\mathrm{X}, \mathrm{O}$; Cooper $195 \mathrm{I}$ and unpubl.) ; except possibly for a cytological form of Nannochorista dipteroides Till. ( $\mathrm{n}=9$ ?, Bush 1967 ), it is indeed the lowest number so far claimed for Mecoptera. A second strain of $N$. dipteroides $(\mathrm{n}=c a \mathrm{I} 4)$, Chorista australis Klug. $\left(\mathrm{n}^{\pi}=\mathrm{I} 4+\mathrm{X}, \mathrm{O}\right)$ (both in Bush 1967), and three species of Bittacus $\left(\mathrm{no}^{*}=\mathrm{I} 3+\mathrm{X}, \mathrm{O}\right.$; $\mathrm{n}_{0}{ }^{*}={ }_{14}+\mathrm{X}, \mathrm{O} ; \mathrm{n}_{0^{*}}={ }_{15}+\mathrm{X}, \mathrm{O}$ ) (Matthey 1950; Atchley and Jackson 1970), all lie within the range of Boreus. My prepararations of a single male of Merope tuber Newm. display chiefly very drawn-out early diakinetic chromosomes, and are sufficient only to establish that it is $\mathrm{XO}$, chiasmate, and has a haploid number that is less than $\mathrm{n}_{0}={ }_{12}+\mathrm{X}, \mathrm{O}-$ possibly $\mathrm{n}^{\top}={ }_{10}+\mathrm{X}, \mathrm{O}$. Though, at this time no more definite statement can be made for our most primitive mecopteran, it is nevertheless clear evidence that the chromosome number of Merope is not a relatively high one. On the other 
hand, the seven species of Panorpa so far reported upon by Naville and de Beaumont (1934), Kichijo (1943), Ullerich (196r), and Atchley and Jackson (1970) stand apart, having the highest chromosome numbers known for Mecoptera; they are: $\mathrm{n}^{\pi}=20+\mathrm{X}, \mathrm{O}$, $\mathrm{n}^{\pi}=2 \mathrm{I}+\mathrm{X}, \mathrm{O}$, and $\mathrm{n}^{\pi}=22+\mathrm{X}, \mathrm{O}$ (4 species, plus one with $\mathrm{n} \varphi=23)$.

The cytology of Panorpa is thus characterized by two evolutionary differences from most other Mecoptera now known: absence of chiasmata at meiosis in the male, as Ullerich ( I96I) first demonstrated, and unusually high diploid numbers. Whether or not male Nannochoristids and Choristids have chiasmata is not known, although Bush's ( 1967) account indicates that male Nannochorista dipteroides, like Panorpids, may have a meiosis without chiasmata.

Despite the strongly derived nature of the external morphology of Boreids, and especially of Boreus notoperates, therefore, their chromosome numbers and possession of chiasmata at meiosis in the male appear conservative. Congruent also with a primitive state is their possession of panoistic ovarioles, as is known also for $B$. brumalis (Cooper 1940) and B. nivoriundus (unpubl.). It is likely that this is the case also for B. hyemalis; Steiner (1937) could find no nurse cells in its ovaries, but was undecided as to whether the ovarioles are panoistic or meroistic.

\section{Oviposition}

As commented above, both male and female Boreus mate repeatedly and with varied partners. In $B$. notoperates the spermatheca of the female has some 24 sperm receptacles (fig. 9, Cooper 1972), all of which come to be filled with spermatozoa. The natural promiscuity may be seen as tending to reduce close inbreeding within the small, scattered populations. In the laboratory, females lay within two weeks following their first mating, and perhaps within a few days as is the case for B. hyemalis (Strübing 1950, 1958).

The large majority of the eggs at laying (which measure from 0.5 to $0.6+\times 0.3+\mathrm{mm}$, length by width $)^{10}$ by $B$. notoperates are placed singly, vertically, and ordinarily at such a depth that the apex of the egg lies from 0.I to $0.3 \mathrm{~mm}$ below the surface of the sod of the moss, amid its rhizoids. Sixteen females, over a period of ten days at $2 \mathrm{I}^{\circ} \mathrm{C}$, laid $\mathrm{I} 86$ eggs that I was able to locate - assuredly a

\footnotetext{
${ }^{10}$ The egg widths in Cooper (1972), p. 275, should of course be $0.31 \mathrm{~mm}$ and $0.30 \mathrm{~mm}$ respectively.
} 
minimal number - giving an average of I.I6 eggs per day per female. The span of life of a female in such cultures was no more than four weeks. Were such a rate of laying maintained, a laboratory-held female would be expected to lay about 32 eggs. At death, these females possess mature eggs in their ovaries, and so their potential fecundity is higher than just estimated. These experiences are in line with those of Withycombe (1922) and Strübing (1950, 1958) for B. hyemalis, although their estimates that the average female lays a maximum of ten or so eggs in a lifetime I suspect to be much too low, considering the hazards of egg development, larval life, and the full two-year life cycle that must be met. Females of $B$. brumalis and $B$. nivoriundus which I have dissected at the close of their seasons in late February and March, still have a few mature eggs in their oviducts, as Strübing (1950) found for B. hyemalis, but in some there is widespread involution of follicles within the ovarioles, the epithelium of the egg chambers incomplete, with many nuclei lying within large protoplasmic masses that simulate nurse cells.

I have not witnessed oviposition, but Brauer ( 1855 , see fig. 5, plate III), Aubrook (1939) and Maréchal (1939) have described females, nearly perpendicular, with ovipositors buried in the soil. Only Svensson (1966), however, has witnessed actual oviposition (perhaps in B. westwoodi, as in Brauer's case), and described the passage of the egg along the incomplete tube formed by the gonapophyses and tergite- $X$. When the egg reaches the tip, the cerci are flexed ventrally, forcing the egg out onto the ventral surface of the gonapophyses. The egg is thereupon set down upon a moss stem, the whole process taking 3 to 4 minutes. It is to be noted that the female he observed laid 4 eggs within a period of two hours, lending some credence to the belief that females of Boreus may actually lay at least again as many eggs as Strübing estimates for the total production of a female B. hyemalis. Indeed Strübing (1950) records one clump of seven eggs, presumably laid by a single female. Certainly it is reasonable to assume that laboratory conditions are not ideal for oviposition, and that such estimates do represent minima.

\section{HATCHING}

Hatching occurred in laboratory samples of eggs of $B$. hyemalis within 8 to ro days, at $8.8^{\circ} \mathrm{C}$, with about $50 \%$ mortality in Withycombe's (1922) series; in contrast, Strübing's (1950) samples took from 3 weeks at approximately $20^{\circ} \mathrm{C}$ to as long as one and a half 

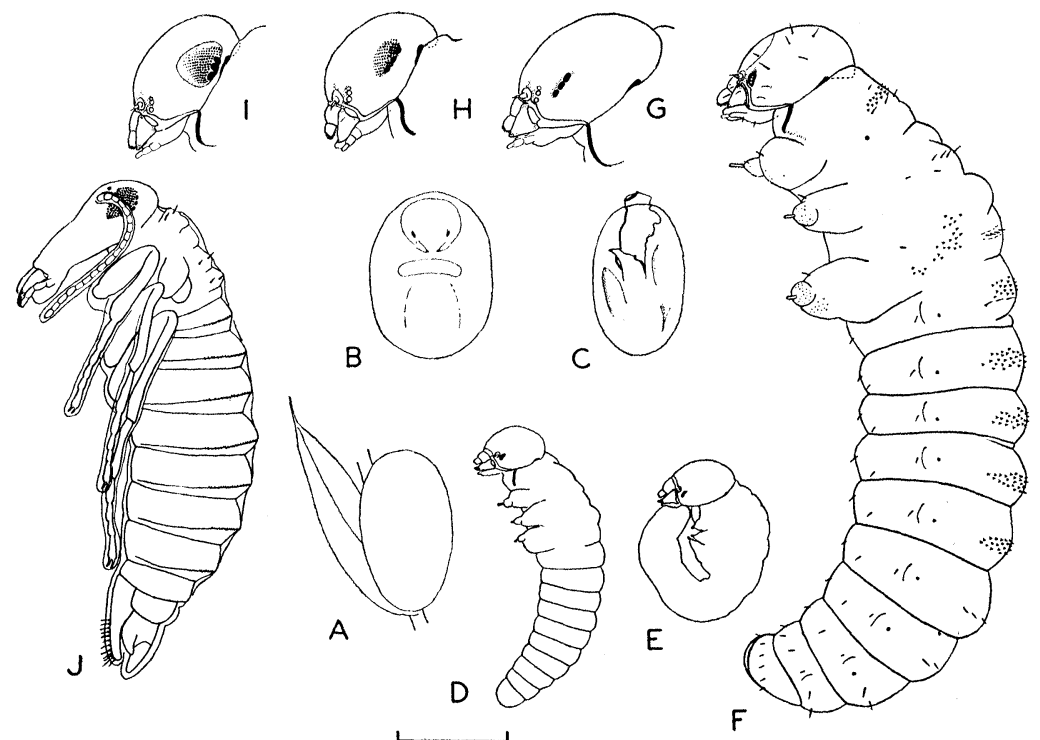

Fig. 3. Immature stages of Boreus notoperates. A, freshly laid egg. $B$, egg just before hatching - note larval head, transverse band, margins of reflexed end of abdomen. C, rent chorion following hatching. D, first instar larva. E, first instar larva dissected from egg at stage comparable to B. F, last instar larva - especially note conformation of pigment underlying stemmata ( $\mathrm{KOH}$ preparation). G to I, pharate pupal heads - note change in both position and conformation of eye pigment, and its relation to the development of the imaginal eye. $J$, pharate adult female - note connections between imaginal fixed setae of gonapophyses and corresponding setae of pupal exuvium. Scale $=0.5 \mathrm{~mm}$, applies to figs. $F$ through $\mathbf{I}$; scale $=1 \mathrm{~mm}$ for $\mathrm{J}$; for dimensions of eggs and first instar larvae, see text.

months at $7^{\circ} \mathrm{C}$, and 44 of 46 eggs of her series hatched. In the case of $B$. notoperates, two of four eggs kept at $20^{\circ} \mathrm{C}$ hatched in a period of 24 days; the other two were at the stage of hatching at that time, but the larvae died without perforating the chorions.

The four freshly laid eggs of $B$. notoperates which $\mathrm{I}$ followed swelled, in the first 15 days, from $0.5 \times 0.3 \mathrm{~mm}$ to $0.66 \times 0.46 \mathrm{~mm}$ $-0.68 \times 0.50 \mathrm{~mm}$, at which time the larval head, pigmented eyes, jaws (mostly held open, but moving from time to time), and reflexed abdomen could be seen, as well as a grayish, transverse band that had appeared on or near the chorion below the larval head (figs. $3 \mathrm{~B}, \mathrm{E}$ ). 
By the next day (day I6) the larvae moved occasionally within the chorions. By day i 8 the larval gut appeared swollen and gray. Over the next five days the larvae became very active, even reversing their positions within the eggs; at times the chorion of an egg would collapse inwards, only to reinflate once again. On the 24th day two of the larvae hatched by means of great rents torn through the chorion (fig. ${ }_{3} \mathrm{C}$ ). I did not observe the emergence, or how the chorion was torn open. As there is no egg burster such as Gassner (1963) has described for the first instar larva of Panorpa nuptialis Gerst., it is possible that infolding of the chorion, as earlier observed, enables the larva to seize and rip the chorion with its jaws, or that the gray band on the chorion is associated with a local weakness. Strübing (1950) has described the swelling of the developing egg (which also occurs in other Mecoptera, see Currie 1932, Setty 1940, Byers 1963), and the hatching of $B$. hyemalis which takes but IO-I 2 minutes; the events prior to hatching are similar to those of $B$. notoperates. ${ }^{11}$

The newly hatched larva of $B$. notoperates (fig. $3 \mathrm{D}$ ) is dead white, except for the pale amber head capsule, darker jaws, and pig-

\footnotetext{
${ }^{11}$ Some 127 developing eggs of B. notoperates were at hand when this passage was written (Feb. 1974). Subsequently they were divided into two lots of which one (of 88 eggs) was followed daily to hatching. All had been kept at $9^{\circ} \mathrm{C}$, and were at a mean age of approximately 30 days when removed to $20^{\circ} \mathrm{C}$ for observation. They had all undergone swelling, but no other sign of development was discernible. The smallest egg was $0.58 \times$ $0.44 \mathrm{~mm}$, the largest $0.78 \times 0.52 \mathrm{~mm}$, and the most distended in girth was $0.64 \times 0.56 \mathrm{~mm}$. In what follows, day 0 is the day of removal (Jan. 14, 1974) to $20^{\circ} \mathrm{C}$.

At day +15 eyes were visible in nearly all eggs; at +21 heads pale testaceous, eyes black, mandibles very dark and active; most eggs alike in stage - despite this, hatching spread out over a period of 36 days.

Hatch was $93 \%$ ( 82 of 88 eggs; 2 did not mature, 3 failed to hatch but had had active larvae, 1 killed by mold). First egg to hatch was at +25 days, half of the eggs had hatched at +31 , three-quarters at $+33,90 \%$ by +38 , and the last on +61 .

Unlike the mandible of the last larval instar, that of the unhatched larva has a sharp, falcate, apical tooth, a moderately long, sharp, subapical tooth, and two successively smaller, sharp denticles. When hatching commences, the turgid chorion is abraded, then penetrated, by the mandibles, whereupon it collapses somewhat and folds inward to a varying degree, owing to loss of fluid from the egg. Within an hour, or as long thereafter as several days, the larva emerges. It does so by cutting through the fold, and elsewhere, to produce a broad apical flap, or even a free cap to the egg. By peristaltic movements, especially of the thorax, the larva forces the flap and emerges through the gaping hole in the chorion in a matter of ten to twenty minutes.
} 
mented eyes. It has a head width of $0.28 \mathrm{~mm}$, widest girth across the thorax of $0.3 \mathrm{~mm}$, and a body length of $0.9 \mathrm{~mm}$. It is not provided with abdominal prolegs, as described by Brauer (1855, fig. 7 , pl. III ; I863, fig. 2, pl. XIV) for $B$. westwoodi, but the terminal abdominal segment does serve, and very effectively so, as a holdfast as he believed.

The two hatched larvae were placed on a small mat of damp moss into the sod of which they speedily disappeared. Seventeen days later the larvae were torpid, stretched out and turgid, and remained so for the next four days. At that point the head capsule was $0.3 \mathrm{~mm}$ wide, the metanotal girth $0.38 \mathrm{~mm}$ (the broadest portion of the thorax), and the total body length $1.04 \mathrm{~mm}$ in one, $1.42 \mathrm{~mm}$ in the other. If, at this point, they were ready for the first larval moult, then the first instar is completed within 16 to 17 days at $20^{\circ} \mathrm{C}$. Unfortunately observations had to be discontinued, and the larvae were preserved.

Strübing (1950, 1958) has shown that the rate of development in $B$. hyemalis is strongly affected by temperature and, unlike the adult, eggs and larvae develop only very slowly, if at all, at the low temperatures of winter. Indeed the egg remains dormant through the winter months, normally hatching in the period from the end of March to mid-April. Hatching is almost certainly earlier in the case of $B$. notoperates for, by the close of January and February, air temperatures above $2 \mathrm{O}^{\circ} \mathrm{C}$ and warm sunshine are not uncommon in its habitat on Mt. San Jacinto.

\section{LARVA}

During the last two weeks of August and in September, larvae, pharate pupae (Hinton 197I, I973), and pupae of B. notoperates are found in the sod of host mosses, amid the rhizoids. The apparent larvae are of two size classes: (I) with a mean head length from the tip of the labrum to the occiput of $0.49 \mathrm{~mm}$, range $0.47-0.52 \mathrm{~mm}$, and a coefficient of variation ( $V$ ) of 5.7 (6 specimens), and (2) with a mean head length of $0.68 \mathrm{~mm}$, range $0.59-0.87 \mathrm{~mm}$, and a surprisingly large $\mathrm{V}$ of 9.7 (23 specimens). Though smaller larvae of the second class proved to be males, and the larger females, the size distribution is not bimodal. No doubt their high coefficient of variation is in part a consequence of two factors: a sexual difference in size at the last instar, and the consequences of the larval-pupal apolysis that closes the larval stage and which I did not detect until later. They proved a heterogeneous lot of last instar larvae and pharate pupae. 


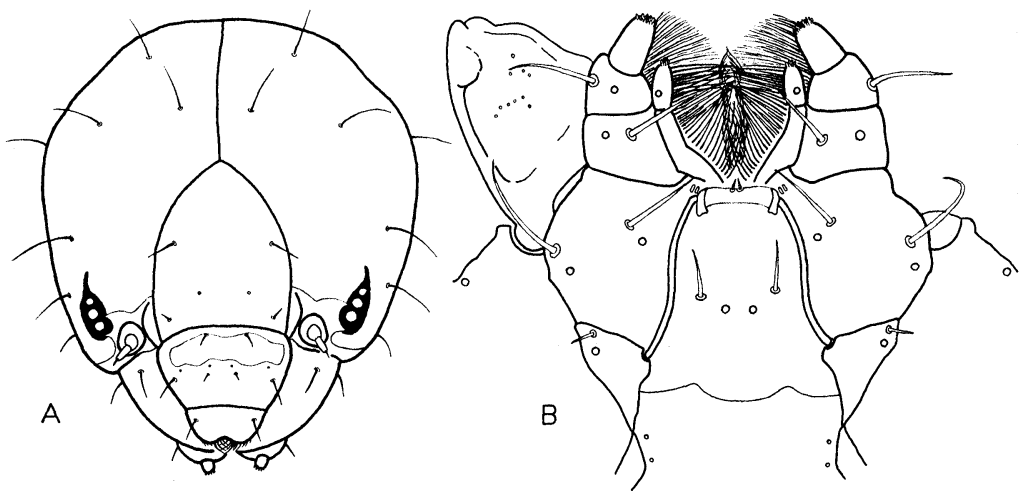

Fig. 4. Head of last instar Boreus notoperates. A, frontal view. B, mouthparts in ventral aspect. For details see text. Full scale $=0.4 \mathrm{~mm}$ for $\mathrm{A},=0.2 \mathrm{~mm}$ for $\mathrm{B}$.

The number of larval ecdyses is not known for any species of Boreus, but it is very likely four as in other species of Mecoptera (Currie 1932, Setty 1940, Byers 1963). The ratio of the mean head length of the larger larvae and pharate pupae to that of the smaller larva is 1.38. This gives estimated head lengths for the two immediately preceding larval stages as $0.36 \mathrm{~mm}$ and $0.26 \mathrm{~mm}$ respectively. As the head length of the first instar larva is known to be $0.32 \mathrm{~mm}$, the series ends there and the number of instars is thus very likely four. The probable Dyar constant of I.29 (which is low compared with Byer's figure of I.46 for Panorpa nuptialis) gives a calculated head length of $0.4 \mathrm{I} \mathrm{mm}$ for instar-2, of $0.49 \mathrm{~mm}$ for instar-3, and of $0.68 \mathrm{~mm}$ for instar-4. Strübing (1950) left the matter of the number of larval instars of $B$. hyemalis open. Withycombe (1922), also unable to find larval exuvia, judged from head capsule growth that there are at least four instars. Though Strübing's measurements of larval head capsules are in fact heterogeneous, they are reasonably well satisfied by a Dyar constant of 1.34 and four instars.

The full grown larva of $B$. notoperates is remarkably similar to the first instar larva (compare figs. $3 \mathrm{D}$ and $\mathrm{F}$ ). The head is pale amber in color, the body white to pale yellow, and in life it ranges from $2.6-3.7 \mathrm{~mm}$ in length. In shape it is "scarabaeiform," to use Peterson's (I95I) characterization of the larva of $B$. brumalis. As 
illustrated (fig. $3 \mathrm{~F}$ ), the larva of $B$. notoperates has localized patches of denticles on the dorsum of the pronotum, a transverse row of setae on the mesonotum, two rows of setulae enclosing a row of setae on the metanotum, an oblique scattering of denticles on the flanks of the metanotum, and patches of denticles on each of the indistinctly 3-segmented legs. Abdominal tergite-I has a dorsal transverse patch of denticles behind which stands a row of setae. Abdominal tergites-2 through 5 have dorsal, transverse patches of denticles, and each segment thereafter possesses only a transverse row of setae, except for segment-IO which is encircled by a row of setae. Though not appearing unusually modified, the apical abdominal segment serves, as in the first instar larva, as an adhesive holdfast. Denticles and setae alike are pale testaceous. As usual for Mecoptera, there are 9 spiracles: one on the flank of the pronotum, and one on each of abdominal segments-I to 8 .

The larval head (fig. $4 \mathrm{~A}$ ) is convex and more or less ovoidal in face view. At the bases of the mandibles, lower halves of the antennal sockets, on the transverse sclerotized plaque on the proximal portion of the clypeus, the head is bright castaneous, as are the mandibles (except for their piceous tips and the cervical sclerites), all contrasting markedly from the pale ground color. The eyes possess three stemmata, the lower two of which have very convex lenses while the uppermost is smaller, flat and somewhat atrophied. Underlying and surrounding the stemmata is a distally attentuated patch of black pigment. The antennae have two obvious segments, and terminate in a bristle-like prolongation that may or may not be a true segment. Coronal, frontal and epistomal sutures are well marked and complete. The clypeus is roughly trapezoidal, the labrum apically emarginate; together they conceal the biting edges and tips of the closed mandibles.

Almost all of the setae described and designated by Boese (1973) for the larval head of Panorpa species are to be found, similarly situated, in $B$. notoperates. The differences between $B$. notoperates and Panorpa species lie in the absence in Boreus of a pair of setae (SO) immediately dorsal to the eye, the presence of but a single pair (instead of 2 pair) of setae (SI) on the labrum which, in addition, are not marginal as in Panorpa, the presence of but a single pair of setae on the mandibles (instead of 3), and the possession of an extra pair of setae, lacking in Panorpa, on the proximal edge of the medial third of the sclerotized clypeal band, just below the epistomal suture. In view of the notable differences between Boreus and Panorpa in 
other aspects of larval and adult anatomy, the complex setation of the larval head appears to have been remarkably stable.

The mandibles of $B$. notoperates (fig. $4 \mathrm{~B}$ ) are massive, triangular, strongly sclerotized, and thrown apically into three, poorly demarcated, blunt teeth. Maxillae and labium are membranous. The maxillary cardo is triangular, the stipes large and trapezoidal, the palpifer (which seems a basal palpal joint) cylindrical and surmounted by the subequally 2-jointed maxillary palps, the terminal joint of which is cylindrical and densely papillate apically. A brush of closely set long hairs is directed medially from each maxillary lobe. The 2jointed labial palps are slender and very elongate. Like the maxillary palps, they are testaceous, and bear a cluster of small pegs at their tips. The prementum, which is strap-like and sclerotized, bears two stout, convergent setae medially at its anterior margin. The submentum is large, trapezoidal, and broader posteriorly.

The numbers and arrangements of setae on the submentum, prementum, basal joint of the maxillary palpi, and possibly of the cardo, are similar to those figured by Potter (1938a) for B. hyemalis. B. notoperates, however, appears to have one less seta on both the palpifer and stipes, and the conformation of palps, maxillary brushes, prementum, and mandibular teeth differ strikingly from that species. It also differs from $B$. hyemalis in shape of head, the presence of a complete frontal suture, a distinct epistomal suture, a sclerotized clypeal band, emarginate labrum, and details of setal pattern. Brauer's ( I 855, I863) descriptions and figures of $B$. westwoodi do not permit a comparison with $B$. notoperates, but I agree with Potter (I938a) that there is no spinneret on the labium as Brauer considered possible and as Withycombe (I922) claimed. If Brauer is correct that the labial palps of $B$. westwoodi are 3 -jointed, that is a very striking difference from B. hyemalis and B. notoperates. Peterson's (I95I) brief description and figures are sufficient to show that the larva of $B$. brumalis has notable differences from both $B$. hyemalis and $B$. notoperates in head shape, labrum, sutures (only an epistomal suture is figured), and setal distribution and lengths on both head and body.

It is important to emphasize that presence of a distinct epistomal suture in the larvae of $B$. notoperates, $B$. brumalis, and $B$. westwoodi, because its supposed absence in Boreus is one of the characteristics emphasized by Hinton (1958) as a feature of Crampton's (I930) suborder Neomecoptera, only diffidently suggested by Crampton, which Hinton elevated to ordinal status. Nor is it the case, as Hinton supposes, that the eleventh abdominal segment of adult female 
Boreus differs from that of other Mecoptera by lacking cerci; Byers (196I) showed their presence in B. brevicaudus, and I confirm their presence in $B$. notoperates as well. As Hepburn (1970) has already said, attempts to remove Boreidae to an order separate from the Mecoptera seems unjustified at this time.

\section{Pupa}

The metamorphosis to the pupa occurs in mid-August and in September in B. notoperates as in the other Boreus for which pupation has been recorded. Its onset is first recognizable by a separation, elongation, hypertrophy and migration of the pigment of the larval eye. The pigment becomes aligned and compacted as three nodes which, at $20^{\circ} \mathrm{C}$, over a period of a week or more, move as a unit posteriorly and obliquely to the orbital region of the head (figs. $3 \mathrm{~F}-\mathrm{I})$. For most of this period the larval jaws are functional, although feeding does not occur, and the larva moves about readily if disturbed.

During migration of the pigment, the purplish compound eye develops as though its posterior edge, defined by the three nodes of black pigment, were its developmental origin of growth. By the time that the imaginal eye is nearly fully outlined (fig. $3 \mathrm{I}$ ), the larvalpupal apolysis has been completed, and the pharate pupa no longer can move the larval mandibles. Evidently this remarkable sequence occurs in at least some beetles as well. The migration of the pigment of the larval eye to the rear of the head in Duvalius mallaszi subsp. chappuisi Jean., described and figured from preserved specimens by the puzzled Jeannel (1926), is certainly an example of the same phenomenon; his specimens in which the pigment had separated from the stemmata are clearly pharate pupae.

It is during the migration of the components of the developing pupal eye that spermatogenesis occurs in B. brumalis (Cooper 1940) and $B$. nivoriundus, and not in the last instar larva as I stated earlier. In $B$. notoperates, however, only spermatogonial divisions and early prophase stages of the first meiotic division occur in the pharate pupa, the meiotic divisions and spermiogenesis taking place in the late pupa and pharate adult.

Within one to several days following apolysis, the larval-pupal ecdysis ensues. Initially the pupa, in contrast to the greasy-yellow, late pharate pupa, is a translucent white with the tips of the mandibles brown, and the eyes a purplish brown. Within a week the body 
yellows, the moveable mandibles become testaceous to their bases, the eyes brown, yet with the three contrasting black nodes at their caudal margins distinct, and ocelli purplish, the malpighian tubules brown, and the bristles amber-brown. Within two weeks the eyes have become black, the three pigment nodes are still discernible, the ocelli are dark sepia, and the malpighian tubules are a dark purplish-brown. At five weeks the jaws and body are still moveable, but the pupaladult apolysis has occurred. It is interesting that in the pharate adult female, the heavy black fixed setae of the gonapophyses attenuate near their midpoints; their threadlike prolongations (which are lost at ecdysis) connect with the corresponding setae of the pupal cuticle (fig. $3 \mathrm{~J}$ ). The pharate adult stage, during which the entire body, wings and legs of the imago darken, may last from ten days to three weeks. The pupal to adult ecdysis thus takes place (in the laboratory) from a month and a half to nearly two months after the onset of pupation. Unlike $B$. hyemalis (Withycomb 1922, Fraser 1943, Strübing I950) and $B$. westwoodi (Brauer I857, I863), in which the newly eclosed adult requires from a number of days to as much as a week to reach full color, but like B. brumalis (Williams r9r6), $B$. notoperates is fully colored within a half day following eclosion. Just how long the true pupal and adult stages last in other Boreus is not known. Until Hinton (1971, 1973) straightened out the matter, and called attention to it, the importance of dating the stages from their apolyses, rather than from their ecdyses, had not been appreciated. Strübing (1950, 1958) gives a duration for the "pupa" of $B$. hyemalis (as from) 40 to 59 days.

\section{Habitat}

The larvae and pupae of $B$. notoperates are found in the sods of mosses growing on diorite boulders from moderate ( $2 \mathrm{ft}$. dia.) to gigantic size. The immature stages occur in a very scattered distribution, and I have not been able to forecast, when the moss is of an appropriate species, whether or not a given moss-covered boulder will be found to be inhabited by Boreus. Ordinarily specimens are few amid the moss of a given boulder but, when found, tend to be clustered.

Initially I was unable to find immatures in the dry summer months. Because the mosses and their sods are very compact, desiccated and crumbly at that time, and frequently at a temperature (when sunned) of $30^{\circ} \mathrm{C}$ or more, it seemed likely that, following 
melting of the snow, the young stages were washed to the ground, thereafter burrowing into the soil. Following that, they would forage as saprophiles, since Withycombe (1922) has found that larvae can feed on leaf mold. Promising moss-covered boulders, standing on a loose, fine and sandy soil, were therefore trenched on the run-off side to a depth of a foot or more, and the soil carefully sifted through Tyler screens down to 16 meshes to the inch (0.99 $\mathrm{mm}$ openings). This seemed a hopeful attack at the time because Strübing (I950) had found that $B$. hyemalis, during periods of drought, descend to a depth of as much as $20 \mathrm{~cm}$ below their mosses, which grow on soil, to reach a suitably humid surrounding. No Boreus were found.

During one collecting period in mid-August there was a brief but heavy shower which, within 20 minutes, brought the mosses on the boulders to a fresh, expanded green state, and soaked their sods through. When the damp sods were broken or sliced open, there amid the rhizoids were the larvae and pupae within small ellipsoidal and cylindrical spaces that had readily cleaved open! During dry periods these cells, which are only slightly larger than the stages enclosed, harden and act thereafter as a coherent whole, appearing as no more than larger, compact particles of the sandy soil and organic debris of the desiccated sod. When such sods are broken and crumbled, these cells remain intact, even under the stresses of sifting. Their inner walls are very smooth, and are perhaps cemented by salivary secretions, but not by silken threads as has been suspected or claimed for the pupal chambers of B. westwoodi (Brauer I863) and $B$. hyemalis (Withycombe 1922, Syms 1934). It is possible that salivary secretions also make their walls impervious to water loss. Thereafter search became routine during the predominantly dry periods for the desiccated mosses on their boulders need only to be soaked with water.

It is clear that $B$. notoperates is well adapted by its earthen chamber for survival during periods of drought. The larva must do most of its foraging during the spring before the moss turfs become dry, and thereafter as infrequent opportunity permits following scattered storms on the mountain.

\section{Associated Mosses}

Records of the mosses with which Boreus is associated in one way or another have been made for only seven or eight of the twentyseven or so species of Boreus known (species list in Svensson 1972), 
and for but four species are the mosses known upon which the larvae feed. I shall bring these records together and discuss them at another time. Suffice it to say that more than forty species of moss are involved, and that these are distributed among 9 orders, 19 families, and 28 genera. The families of mosses for which a member (or members) is known to support the life history of a species of Boreus are Dicranaceae, Bryaceae, Mniaceae, Thuidaceae, and Polytrichaceae. Records which follow for $B$. notoperates now add two additional families: Grimmiaceae and Orthotrichaceae. The generic and specific names are those recognized by Crum, Steere and Anderson (I973).

B. notoperates uses as food and habitat for its larval stages: Grimmia apocarpa Hedw., G. montana B.S.G., Rhacomitrium sudeticum (Funck.) B.S.G., and Orthotrichum rupestre Schleich. ex Schwaeger. Each is widely distributed, being found in Europe, Asia, and North America. Adults have been collected on all of the above, as well as on the following: Grimmia laevigata (Brid.) Brid.; Tortula princeps De Not. and T. ruralis (Hedw.) Gaertner (Pottiaceae); Homalothecium aeneum (Mitt.) Lawt., H. nevadense (Lesq.) Ren. \& Card., H. pinnatifidum (Sull. et Lesq.) Lawt., and Camptothecium amesiae Ren. \& Card. (all Thuidaceae). The identifications of all of these mosses have been made by Professor Lewis E. Anderson of the Department of Botany, Duke University, Durham, N.C., and voucher specimens have been retained in the herbarium at Duke University.

Adult $B$. notoperates will browse in the laboratory on all of the mosses listed above. But of the mosses upon which only adults have been collected, only Grimmia laevigata and the two species of Tortula are widely distributed (Eur., Asia, N. A.), and by the nature of their rhizoids and sods are likely candidates as larval habitats and food. The sods of the mosses in which larval and pupal B. notoperates have been found are compact, but surprisingly thin, falling within the range from 5-10 $\mathrm{mm}$ when dry, and from nearly 6-12 $\mathrm{mm}$ when thoroughly damp. The Thuidaceae, on the other hand, are all endemic species. Because their clumps are coarse, open, and generally without a suitably fine rhizoid mat and sod, they are probably not used as larval habitat and food mosses.

It is of particular interest that the mosses which serve as larval food for $B$. notoperates are very widespread; also that $B$. notoperates is not limited to a single species or genus of moss but in fact utilizes members of two families representing different orders (Grimmiales and Isobryales). Whatever limits the geographic distribution 
of $B$. notoperates, it is certainly not the availability of a local or special moss. That generalization holds as well for those other species of Boreus for which associations with mosses have been specifically recorded; nearly all of the mosses concerned are widespread in Europe, Asia and North America, and indeed quite a number have a still more extensive range than that.

\section{Variation Among Adults}

When B. notoperates was described (Cooper 1972), my series of 29 specimens was nearly uniform with respect to antennal joint number, namely i9 joints - a feature used as a specific character. The only apparent exceptions that I noted I did not take to be such; they were a male and female, each of which had an incomplete separation of joints-3 from 4, but these joints were otherwise demarcated by their apical swellings. Since then I have found that individuals do occur with antennal joint numbers other than I9-19.

In a series of 86 males and 83 females held to determine their relative lengths of life in the laboratory $\left(\overline{\mathrm{m}} \mathrm{o}^{x}=\mathrm{I} 6\right.$ days, $\overline{\mathrm{m}} \mathrm{q}=22$ days; $0.05>\mathrm{P}>0.02$ ), the distributions of antennal joint numbers were:

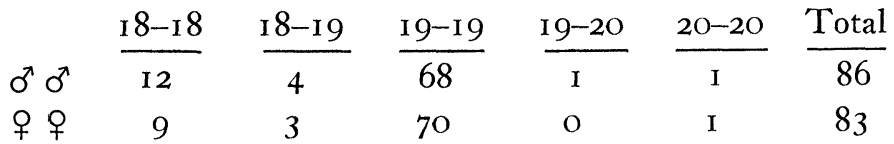

Thus about $12 \%$ of $B$. notoperates have a different antennal joint number than I9-19. When numbers of 19-19 individuals are compared with the lumped totals of the others, there is no evident difference between male and female $(0.8>\mathrm{P}>0.7)$. Males with antennal joints fewer than $19-19$ do tend to die somewhat earlier than the other males $(\overline{\mathrm{m}}=\mathrm{I}$ I days $)$, the Wilcoxon rank sum test giving $0.02>\mathrm{P}>0.01$. Such females also die somewhat earlier $(\overline{\mathrm{m}}=\mathrm{I} 9$ days $)$, but not significantly so, for $0.5>\mathrm{P}>0.4$.

Attention is also called to new information on patterns of abdominal fusions in males (Cooper I973).

\section{Predators, Parasites and Life Cycle}

Very little has been recorded regarding the use of Boreus as prey. Withycombe (1922) was of the opinion that the adult would be expected "to be speedily devoured" by birds, unless distasteful. Greve 
(196) holds Boreus to be acceptable to small birds as welcome supplement to their winter fare, and that Boreus' escape leap and thanotaxis perhaps offer it some protection against predation. No one seems to have observed birds feeding on Boreus, however, and McAtee's extensive analysis of the stomach contents of birds provides no records. Lestage (I940), on the other hand, cites a unique record of the remains of Boreus from the stomachs of trout, even adding "[les] Truites ont montré celles-ci friandes des Boreus"! Other possible predators that have been mentioned are spiders, often abundant on snow during warmer days, and rapacious insects (Vlasov 1950, Greve 1966) - but none have been shown to be such. Definite information, however, can be given on actual and probable parasites of species of Boreus.

In my own experience, I have but once found mites on Boreus. Four adult individuals of a species of Pediculaster (Pyemotidae; determined by Prof. Earle A. Cross) were in neat parallel array, lengthwise to abdominal sternites- $I$ and 2, nearly concealed between the abdomen and the dorsal faces of the metacoxae, on which they were seated, of an adult male of $B$. brumalis (Hanover, N. H., Jan. 8, I96I, air temp. $1.7^{\circ} \mathrm{C}$ ). The record is of special interest for it is a likely, occasional parasite of Boreus. Insofar as the habits of species of Pediculaster are known, they are ordinarily phoretic on a number of diverse flies, and Vitzthum found that P. mesembrinae (Canestrini) drop off their hosts at oviposition sites, attacking there the developing fly larvae (see Cross 1965).

A not surprising second parasite of Boreus is a Cordyceps (Sphaeriales, Clavicipitaceae) that in one case of 5 such emerged from the intersection of the frontal and coronal sutures, as well as from between the 9th and roth abdominal tergites of a mummified 4th instar larva of $B$. brumalis found erect in its vertical burrow just beneath the basal stems of the host moss, Dicranella heteromalla (Hedw.) Schimp. (Princeton, N.J., Nov. 19, 1939). The portion of the fungus from the head bifurcated into two fruiting bodies (each about 3-4 mm long), extending vertically upwards and nearly parallel. The limb from the abdomen bent sharply and vertically upwards, and was nearly $5 \mathrm{~mm}$ long. In all, the 5 Cordyceps-infected larvae were among $25+$ larvae collected that day from one large turf of the moss growing at the base of a tulip tree. Of 35 pupae collected at the same site and time, none were afflicted by the fungus.

The only parasites that have been recorded from $B$. hyemalis are hymenopterous. The braconid Dyscoletes lancifer Haliday was shown 
by Aubrook (1939) and Fraser (1943) to be a parasite of the larva. Withycombe (1922) had earlier reported hymenopterous parasites of the larva, but it is by no means certain that they were also Dyscoletes. Indeed, of the single larval parasite that Withycombe endeavored to rear, but which was destroyed by mold as a pupa, he says that it appeared to be that of an apterous form. At Princeton, N. J., I too obtained hymenopterous larvae from larval $B$. brumalis in the autumn, but was unable to rear them.

From I3 B. notoperates larvae collected at Coldwater Canyon on Mt. San Jacinto (Aug. 22, I973), I 7 hymenopterous larvae emerged ( 3 from I larva, 2 from each of 3 larvae, and I from each of 8 larvae); one additional larva was obtained from a larval cell of Boreus containing the remains of the mecopterous larva. By February I, 1974, only 5 specimens $\left(4+9,1 O^{x}\right)$ had transformed to adults. All are a megaspilid (Ceraphronoidea), and are tentatively identified as an undescribed species of Conostigmus. ${ }^{12}$ It is an interesting association, for so far as I am aware no ceraphronoid is known to have a mecopterous host, although there are records of neuropteroid hosts (e.g., Muesebeck i959, Dessart i967).

Withycombe (1922), who thought - like many others - that Boreus has an annual cycle, was puzzled as to what alternative host a hymenopterous parasite of Boreus might attack from August to December. This, so that it could have a brood appearing early in the new year that could once again parasitize a new generation of Boreus. Syms (1934) and Aubrook (1939), however, conclude from their finding in the autumn, of two stages of the larva of $B$. hyemalis, that Boreus probably has a 2-year life cycle, and Syms actually showed this to be so for at least some larvae. That it does in fact have a 2-year cycle has been proven conclusively by Strübing (1950), and it is very likely that all Boreus have a cycle that normally takes 2 years - assuredly that is so for $B$. notoperates, $B$. brumalis, and $B$. nivoriundus, which I have studied. The problem that Withycombe posed thus vanishes, for the larvae of a second generation of Boreus are available at any time that the hymenopterous parasite emerges and is ready to oviposit. Such parasites of Boreus, therefore, could be specific parasites, having no other host.

In the case of the larva of $B$. notoperates, confined as it is to hard earthen cells for perhaps half of its life, it is likely that the parasite

\footnotetext{
${ }^{12}$ Dr. Paul Dessart, Chef de Travaux, Entomologie, Institut Royal des Sciences Naturelles de Belgique, Bruxelles, has very kindly confirmed the generic placement of Conostigmus (March 11, 1974).
} 
can attack its host only during periods of dampness when the larva of Boreus is free to move about; since the parasite pupates, or may enter diapause, enclosed within the cell of its host larva, parasite and host are thereby synchronized to the same periods of activity. The very means by which the larvae of $B$. notoperates withstands drought thus entrains the parasite to the host's timetable.

\section{Acknowledgment}

I wish to thank those who have helped me in various ways during the course of this work. Especial thanks are extended to Prof. Lewis E. Anderson, of Duke University, for his cheerful acceptance of the numerous samples of mosses sent him over the years for identification. Other plants, still to be mentioned, were collected and identified by Mr. J. W. Stubblefield to whom I owe special thanks. Both he, and my wife, Dr. Ruth S. Cooper, gave me much help with field work that, at times, I could not otherwise have carried out. Prof. Earle A. Cross, of Northwestern State College, La., made the identification of the phoretic mite. Prof. G. W. Byers, of the University of Kansas, obtained for me Tarbinsky's and Vlasov's articles, not available in this country, from a Russian colleague. Prof. Peter Jorgensen, of the University of California at Riverside, helped me with the Scandinavian articles, and as before I have been assisted with Russian works by both Prof. Anatole Forostenko, also of U. C. R., and my son Geoffrey K. Cooper. Errors of interpretation, if any, are however my sole responsibility. Finally, it is a pleasure to acknowledge my considerable indebtedness to Prof. Frank M. Carpenter, of Harvard University, whose unsolicited kindnesses in sending me specimens and literature otherwise unavailable to me, and in other ways, have been of such help in the work on Boreus and other studies.

\section{Literature Cited}

Atchley, W. R. and R. C. Jackson

1970. Cytological observations on spermatogenesis in four species of Mecoptera. Canad. Jour. Gen. Cytol. 12: 264-272.

Aubrook, E. W.

1939. A contribution to the biology and distribution in Great Britain of Boreus hyemalis (L.) (Mecopt., Boreidae). Jour. Soc. Brit. Ent. 2: 13-21.

BOESE, A. E.

1973. Descriptions of larvae and key to fourth instars of North American Panorpa (Mecoptera: Panorpidae). Univ. Kansas Sci. Bull. 50 : $163-186$. 
BraUer, F.

1855. Beiträge zur Kenntniss des inneren Baues und der Verwandlung der Neuropteren. Verh. zool.-bot. Vereins Wien. 5: 701-726.

1857. Beiträge zur Kenntniss der Verwandlung der Neuropteren. Verh. zool.-bot. Gesellsch. Wien. 7: 69-70.

1863. Beiträge zur Kenntniss der Panorpiden-Larven. Verh. zool.-bot. Gesellsch. Wien. 13: 307-324.

Bush, G. L.

1967. The comparative cytology of the Choristidae and Nannochoristidae (Mecoptera). Amer. Phil. Soc. Yrbk. 1966: 326-328.

BYERS, G. W.

1954. Notes on North American Mecoptera. Ann. Ent. Soc. Amer. 47: 484-510.

1955. A new species of Boreus (Mecoptera: Boreidae) from Colorado. Univ. of Michigan. Occ. Pap. Mus. of Zool. \#563: 1-4.

1961. An unusual new species of Boreus (Mecoptera: Boreidae) from Oregon. Jour. Kansas Ent. Soc. 34: 73-78.

1963. The life history of Panorpa nuptialis (Mecoptera: Panorpidae). Ann. Ent. Soc. Amer. $56:$ 142-149.

Carpenter, F. M.

1936. Descriptions and records of Nearctic Mecoptera. Psyche 43: 56-64.

Chapman, J. A.

1954. Observations on snow insects in western Montana. Canad. Ent. 86: $357-363$.

COCKLE, J. W.

1908. The mating of Boreus californicus. Canad. Ent. 40: 101.

1914. The mating of Boreus californicus. Proc. Ent. Soc. Brit. Col. 4: 52-54.

COOPER, K. W.

1940. The genital anatomy and mating behavior of Boreus brumalis Fitch (Mecoptera). Amer. Midl. Nat. 23 : 354-367.

1951. Compound sex chromosomes with anaphasic precocity in the male mecopteran, Boreus brumalis Fitch. Jour. Morph. 89: 37-58.

1972. A southern California Boreus, B. notoperates n. sp. I. Comparative morphology and systematics (Mecoptera: Boreidae). Psyche 79: 269-283.

1973. Patterns of abdominal fusions in male Boreus (Mecoptera). Psyche 80: 270.

Crampton, G. C.

1918. The genitalia and terminal abdominal structures of male Neuroptera and Mecoptera with notes on the Psocidae, Diptera and Trichoptera. Psyche 25: 47-59.

1920. A comparison of the external anatomy of the lower Lepidoptera and Trichoptera from the standpoint of phylogeny. Psyche 27: 23-45.

1923. The genitalia of male Diptera and Mecoptera compared with those of related insects, from the standpoint of phylogeny. Trans. Amer. Ent. Soc. 48 : 207-225. 
1930. The wings of the remarkable archaic mecopteron, Notiothauma Reedi MacLachlan, with remarks on their problattoid affinities. Psyche 37: 83-103.

1931. The genitalia and terminal structures of the male of the archaic mecopteron, Notiothauma Reedi, compared with related Holometabola from the standpoint of phylogeny. Psyche $38: 1-21$.

1940. The mating habits of the winter mecopteron, Boreus brumalis Fitch. Psyche 47: 125-128.

Cross, E. A.

1965. The generic relationships of the family Pyemotidae (Acarina: Trombidiformes). Univ. Kansas Sci. Bull. 45: 29-275.

Crum, H. A., W. C. Steere, and L. E. Anderson

1973. A new list of mosses of North America north of Mexico. The Bryologist 76: 85-130.

Currie, G. A.

1932. Some notes on the biology of the immature stages of Harpobittacus tillyardi. Proc. Linn. Soc. N. S. Wales. 57: 116-122.

Dessart, P.

1967. Description de Dendrocerus (Macrostigma) noumeae sp. nov. de Nouvelle Calédonie (Ceraphronoidea Megaspilidae) Entomophaga. 12 : 343-349.

EsBen-Petersen

1921. Mecoptera. Coll.-Zool. Selys Longchamps. Fasc. V (2), 172 p. Fitch, A.

1847. Winter insects of eastern New York. Amer. Jour. Agr. Sci. 5: 274-284.

FJel.lberg, A. and L. Greve

1968. Notes on the genus Boreus in Norway. Norsk. ent. Tidsskr. 15: 33-34.

Fraser, F. C.

1943. Ecological and biological notes on Boreus hyemalis (L.) (Mecopt., Boreidae). Jour. Soc. Brit. Ent. 2: 125-129.

GASSNER, G.

1963. Notes on the biology and immature stages of Panorpa nuptialis Gerstaecker (Mecoptera: Panorpidae). Texas Jour. Sci. 15: 142-154.

Greve, L.

1966. Skorpionfluer og snelopper. Naturen $90: 346-354$.

HARDY, J.

1848. Note on Boreus hyemalis. Zoologist. 6: 2175.

Hepburn, H. R.

1970. The skeleto-muscular system of Mecoptera: the thorax. Univ. Kansas Sci. Bull. 48 : 801-844.

Hinton, H. E.

1958. The phylogeny of the panorpoid orders. Ann. Rev. Ent. 3: 181206.

1971. Some neglected phases in metamorphosis. Proc. Roy. Ent. Soc. Lond. (C) $35: 55-64$.

1973. Neglected phases in metamorphosis: a reply to V. B. Wigglesworth. Jour. Ent. (A) 48: 57-68. 
JEANNEL, R.

1926. Monographie des Trechinae (Prem. Livr.). L'Abeille. 32: 221550 .

Kichijo, $\mathrm{H}$.

1943. (Nagasaki Med. Jour. 21; not seen - cited from Makino, S. 1951. An atlas of chromosome numbers in animals. 2nd ed. Iowa State Coll. Press, Ames. xxviii +290 p.)

Kolenati, F. A.

1847 (1845). De Gletchergast. Bull. Class. Phys.-Math. l'Acad. Imp. Sci. St. Pétersbourg. 5 : 51-60.

LAMB, C. G.

1922. The geometry of insect pairing. Proc. Roy. Soc. Lond. (B) 94: 1-11.

Lestage, J. A.

1920. Observations sur l'accouplement du Boreus hiemalis. Ann. Soc. Ent. Belge. $60: 46$.

1940. Pour l'histoire des Boreus (Stégoptères-Mécoptères). Ann. Soc. Roy. Zool. Belg. 71 : 1-22.

1941. Pour l'histoire des Boreus, deuxième partie. Ann. Soc. Roy. Zool. Belg. 72: 5-29.

McAtee, W. L.

1923. A biological survey of the Pribilof Islands, Alaska. Part II. Insects, Arachnids, and Chilopods of the Pribilof Islands, Alaska. U.S.D.A., Bur. Biol. Surv., North American Fauna. 46: 129-254.

1932. Effectiveness in nature of the so-called protective adaptations in the animal kingdom, chiefly as illustrated by the food habits of nearctic birds. Smithson. Misc. Coll. 85(7), 201 p.

Maclachlan, R.

1868. Monograph of the British Neuroptera-Planipennia. Family II. Boreidae. Trans. Roy. Ent. Soc. Lond. 1868: 218-220.

Marchal, P.

1911. La spanadrie et l'oblitération de la reproduction sexuée chez les Chermes. C. R. Acad. Sci. Paris. $153: 299$.

MARÉCHAL, P.

1939. Contribution à la connaissance de Boreus hyemalis L. (Mécopt.). Bull. Ann. Soc. Ent. Belg. 79 : 111-116.

MarTynova, O. M.

1954. Skorpionnitsy (Mecoptera) fauny SSSR. I. Trudy. Zool. Inst. Akad. Nauk. SSSR. 15: 54-66.

Matthey, R.

1950. La formule chromosomique et le type de digamétie chez Bittacus italicus Müll. (Mecoptera). Schweiz. Gesellsch. Vereb.-Forsch. Arch. Julius Klaus-Stiftung. 25 : 607-611.

Meisenheimer, J.

1921. Geschlecht und Geschlechter im Tierreiche. Bd. 1. Die natürlichen Beziehungen. Jena. xiv +896 p.

Merriam, C. H.

1898. Life zones and crop zones. U.S.D.A., Div. Biol. Surv., Bull. 10, $79 \mathrm{p}$. 
Michener, C. D.

1944. A comparative study of the appendages of the eighth and ninth abdominal segments of insects. Ann. Ent. Soc. Amer. 37: 336-351.

Muesebeck, C. F. W.

1959. New reared species of Lygocerus Foerster (Hymenoptera: Ceraphronidae). Ent. News. 70: 91-96.

Naville, A. and J. de Beaumont

1934. Les chromosomes des Panorpes. Bull. Biol. Belg. 68: 98-107.

Peterson, A.

1951. Larvae of insects. Part II. Coleoptera, Diptera, Neuroptera, Siphonaptera, Mecoptera, Trichoptera. Edwards Bros., Columbus, Ohio. $v+416 \mathrm{p}$.

Pliginsky, V. G.

1930. Novye vid roda Boreus Latr. (Neuroptera, Panorpidae). Rev. Russe d'Ent. 24: 230-231.

Potter, E.

1938a. The internal anatomy of the larvae of Panorpa and Boreus (Mecoptera). Proc. Roy. Ent. Soc. Lond. (A) 13: 117-130.

1938b. The internal anatomy of the order Mecoptera. Trans. Roy. Ent. Soc. Lond. 87 : 467-501.

RICHARDS, O. W.

1927. Sexual selection and allied problems in the insects. Biol. Rev. 2: 285-364.

SAUER, C.-P.

1966. Ein Eskimo unter den Insekten: die Winterhaft Boreus westwoodi. Mikrokosmos. 55 : 117-120.

SETTY, L. R.

1940. Biology and morphology of some North American bittacids (Order Mecoptera). Amer. Midl. Nat. 23: 257-353.

Steiner, P.

1937. Beitrag zur Fortpflanzungsbiologie und Morphologie des Genitalapparates von Boreus hiemalis L. Zeitschr. Morphol. Ökol. Tiere. $32: 276-288$.

STRÜBING, $\mathrm{H}$.

1950. Beiträge zur Biologie von Boreus hiemalis L. Zool. Beitr. (N.F.) 1: $51-110$.

1958. Schneeinsekten. Die neue Brehm-Bucherei, 220, Ziemsen Verl., Wittemberg Lutherstadt. $47 \mathrm{p}$.

Svensson, S. A.

1966. Studier over vissa vinteraktiva insekters biologi. Norsk. ent. Tidsskr. $13:$ 335-338.

1972. Boreus Latreille, 1825 (Mecoptera). A synopsis of described species. Studies on some winter-active insects. I. Ent. Scand. 3: 26-32.

SYMs, E. E.

1934. Notes on British Mecoptera. Trans. South Lond. Ent. Nat. Hist. Soc. 1933/34: 84-88.

Tarbinsky, S. P.

1960. Lednichnik (Mecoptera Boreidae) v predgor'yach Kirgizskogo Alatoo. Tez. Dokl. Konfer. Kirgiz s. kh. in-ta, Frunze: 37-38. 
TJEDER, B.

1970. Mecoptera, in: Tuxen, E. L. (ed.), Taxonomist's glossary of the genitalia of insects. 2nd ed., Munksgaard, Copenhagen. 359 p. ULLERICH, F. H.

1961. Achiasmatische Spermatogenese bei der Skorpionsfliege Panorpa (Mecoptera). Chromosoma 12:215-232.

USINGER, R. L. AND R. MATSUdA

1958. Classification of the Aradidae (Hemiptera-Heteroptera). Brit. Mus., London. vii +410 .

Vlasov, Ya.P.

1950. Lednichnik (Boreus vlasovi R. Kors. in litt.). Izv. Turkmen. Fil. Akad. Nauk SSSR. 1950 : 62-65.

Williams, F. $\mathbf{X}$.

1916. The pupa of Boreus brumalis. Psyche $23: 36-39$.

Wiтнусомве, C. L.

1922. On the life history of Boreus hyemalis L. Trans. Ent. Soc. Lond. 1921 : 312-318.

1926. Additional remarks upon Boreus hyemalis L. Ent. Mo. Mag. 62 : 81-83. 

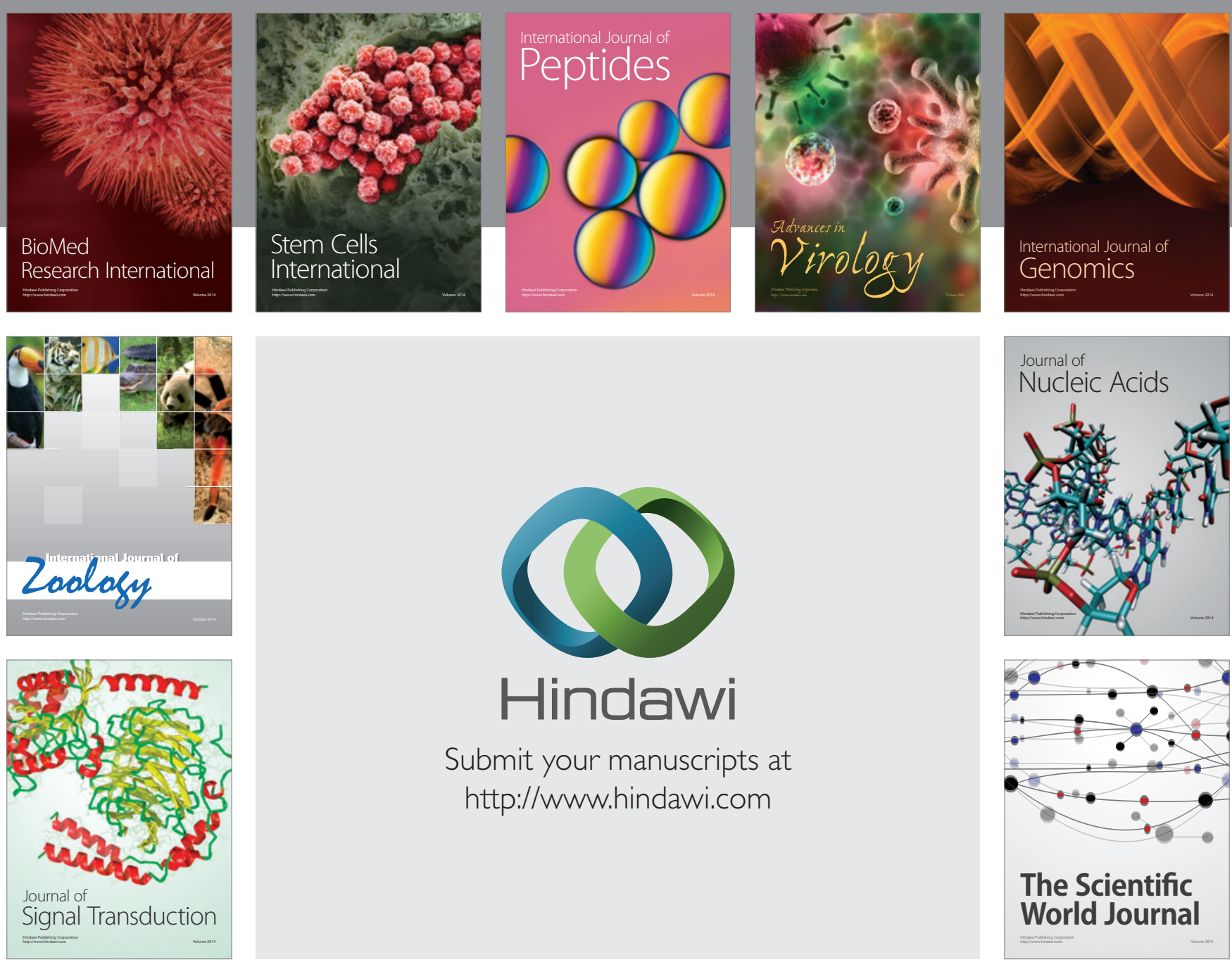

Submit your manuscripts at

http://www.hindawi.com
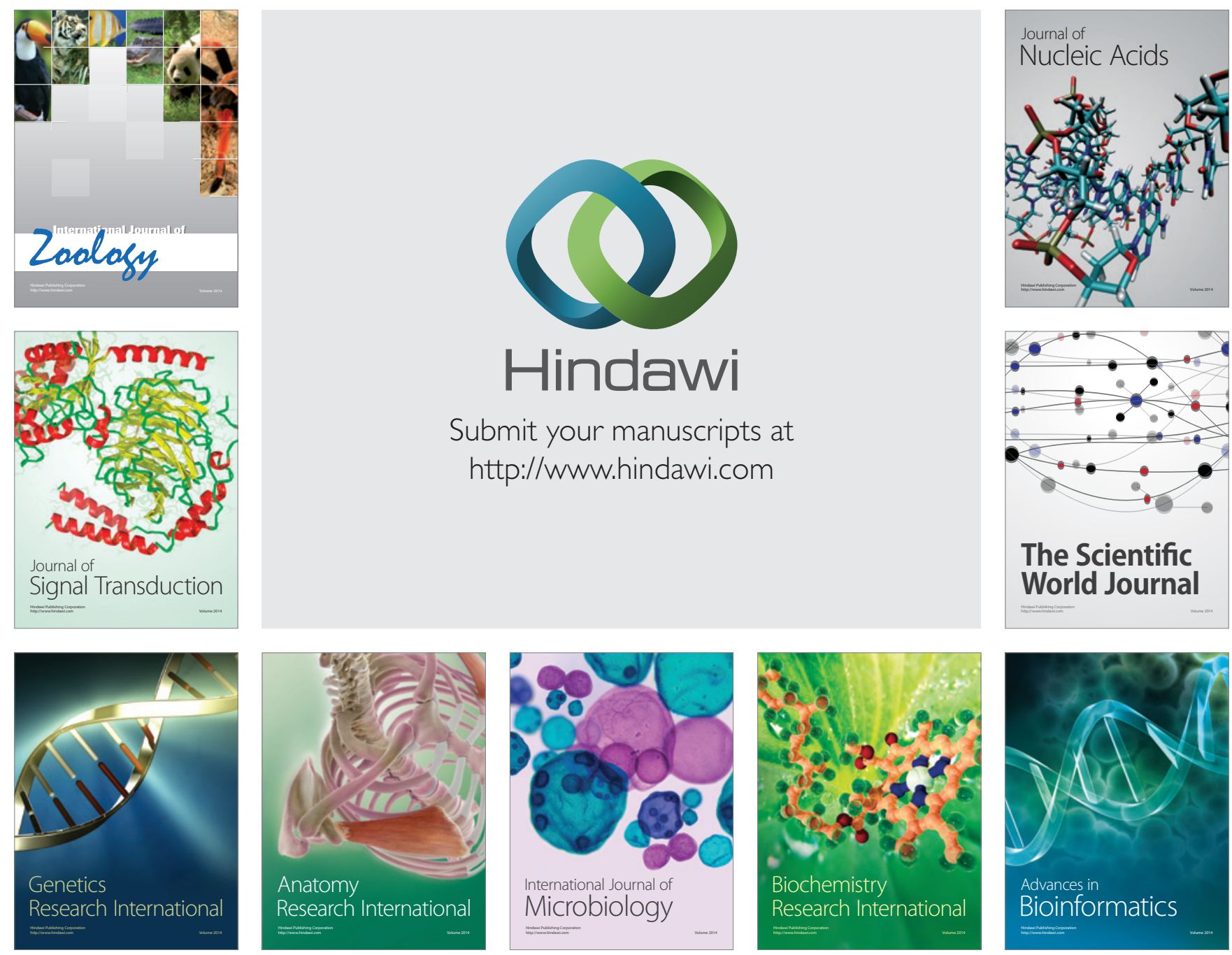

The Scientific World Journal
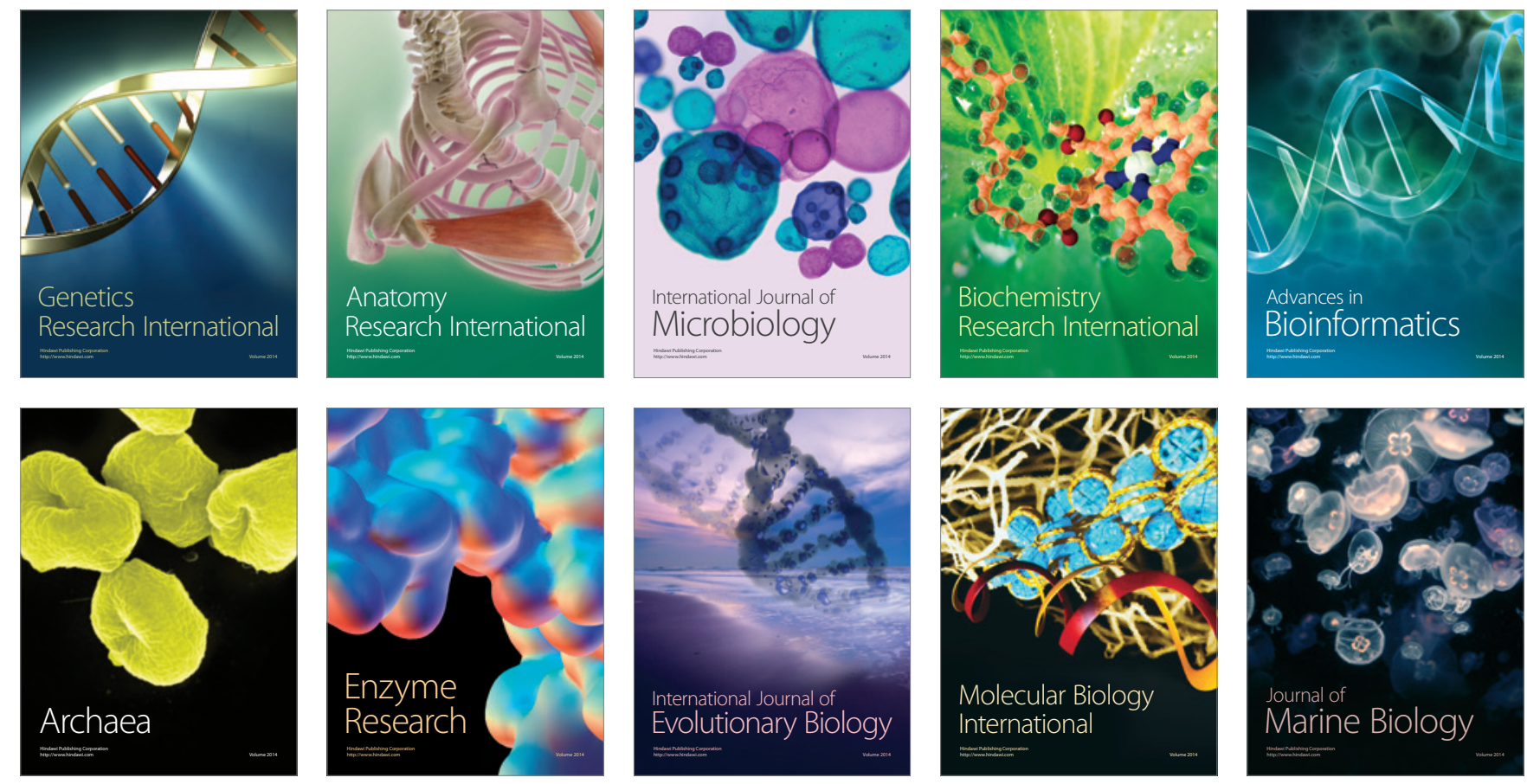